\title{
Congenital Diaphragmatic hernia - a review
}

\author{
Praveen Kumar Chandrasekharan ${ }^{1 *}$, Munmun Rawat ${ }^{1}$, Rajeshwari Madappa², David H. Rothstein ${ }^{3}$ \\ and Satyan Lakshminrusimha'
}

\begin{abstract}
Congenital Diaphragmatic hernia $(\mathrm{CDH})$ is a condition characterized by a defect in the diaphragm leading to protrusion of abdominal contents into the thoracic cavity interfering with normal development of the lungs. The defect may range from a small aperture in the posterior muscle rim to complete absence of diaphragm. The pathophysiology of $\mathrm{CDH}$ is a combination of lung hypoplasia and immaturity associated with persistent pulmonary hypertension of newborn (PPHN) and cardiac dysfunction. Prenatal assessment of lung to head ratio (LHR) and position of the liver by ultrasound are used to diagnose and predict outcomes. Delivery of infants with $\mathrm{CDH}$ is recommended close to term gestation. Immediate management at birth includes bowel decompression, avoidance of mask ventilation and endotracheal tube placement if required. The main focus of management includes gentle ventilation, hemodynamic monitoring and treatment of pulmonary hypertension followed by surgery. Although inhaled nitric oxide is not approved by FDA for the treatment of PPHN induced by $C D H$, it is commonly used.

Extracorporeal membrane oxygenation (ECMO) is typically considered after failure of conventional medical management for infants $\geq 34$ weeks' gestation or with weight $>2 \mathrm{~kg}$ with $\mathrm{CDH}$ and no associated major lethal anomalies. Multiple factors such as prematurity, associated abnormalities, severity of PPHN, type of repair and need for $\mathrm{ECMO}$ can affect the survival of an infant with $\mathrm{CDH}$. With advances in the management of $\mathrm{CDH}$, the overall survival has improved and has been reported to be $70-90 \%$ in non-ECMO infants and up to $50 \%$ in infants who undergo ECMO.
\end{abstract}

Keywords: Lung Hypoplasia, Pulmonary Hypertension, Extracorporeal membrane oxygenation

\section{Background}

Congenital Diaphragmatic hernia $(\mathrm{CDH})$ is characterized by a defect in the diaphragm leading to the protrusion of abdominal contents into the thoracic cavity affecting the normal development of the lungs. The condition may present as an isolated lesion or as part of a syndrome. The incidence of $\mathrm{CDH}$ based on the available literature ranges from approximately $0.8-5 / 10,000$ births and varies across the population [1-4]. There is slightly higher male predominance and a lower risk of isolated $\mathrm{CDH}$ reported among African-Americans $[3,5]$. In spite of advances made in the medical and surgical management of $\mathrm{CDH}$, the mortality and morbidity remain

\footnotetext{
* Correspondence: pkchandr@buffalo.edu

'Department of Pediatrics, Women and Children's Hospital of Buffalo, Buffalo, NY, USA

Full list of author information is available at the end of the article
}

high [6-8]. CDH infants also have a prolonged length of stay in the hospital requiring multi-disciplinary approach for their management and follow-up after hospital discharge.

\section{Review \\ Etiology}

The etiology of $\mathrm{CDH}$ largely remains unclear and currently is thought to be multifactorial. The majority of the cases have an isolated diaphragmatic defect presenting with pulmonary hypoplasia and persistent pulmonary hypertension of newborn (PPHN). CDH can be associated with cardiac, gastrointestinal, genitourinary anomalies or with chromosomal aneuploidy such as trisomies. Multiple genetic factors along with environmental exposures and nutritional deficiencies have been proposed to be the possible etiologies for $\mathrm{CDH}$ [9-11]. Studies in 
rodent models have pointed towards a disturbance in Vitamin A pathway [12]. Nitrofen, a herbicide, when administered to pregnant rodents, results in $\mathrm{CDH}$ in the majority of offspring [13, 14]. Similar effects were seen in WT1 and COUP-TFII mutant mouse models. Studies in neonates with $\mathrm{CDH}$ have shown low retinol and retinol-binding protein levels from cord blood samples $[9,15]$.

\section{Pathology}

Location (Fig. 1): Postero-lateral hernias also known as Bochdalek hernias are the most common type (70-75\%) with the majority occurring on the left side (85\%) and less frequently on the right side (13\%) or bilateral (2\%). Anterior defects or Morgagni hernias (23-28\%) and central hernias $(2-7 \%)$ are the other types $[16,17]$.

Size (Fig. 2): The diaphragm begins to develop at approximately 4 weeks of gestation and is fully formed by 12 weeks [18]. The defect may range from a small opening of the posterior muscle rim to complete absence of diaphragm.

The embryologic basis of $\mathrm{CDH}$ remains controversial. It was thought initially that the defect happened secondary to failure of different parts of the diaphragm to fuse resulting in a patent pleuroperitoneal canal $[19,20]$. Rat models have shown a defect in the primordial diaphragm called the pleuroperitoneal fold [16]. This, in turn, allows the gut to enter the thoracic cavity when it returns from

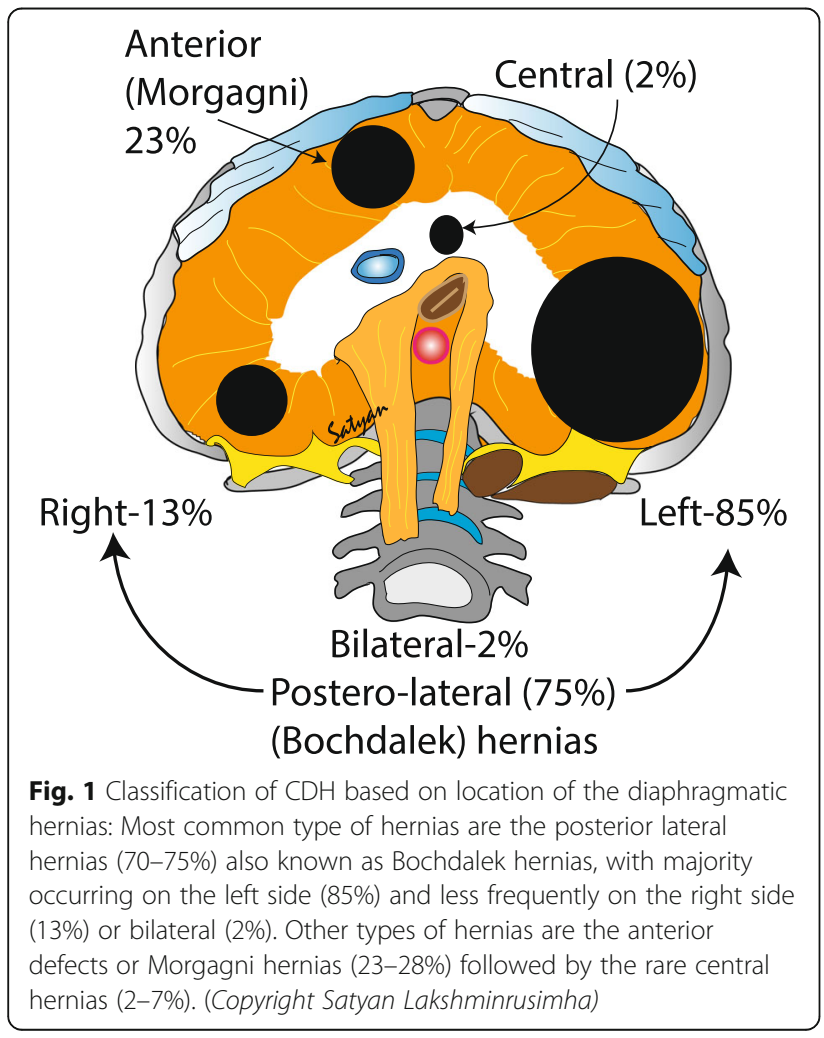

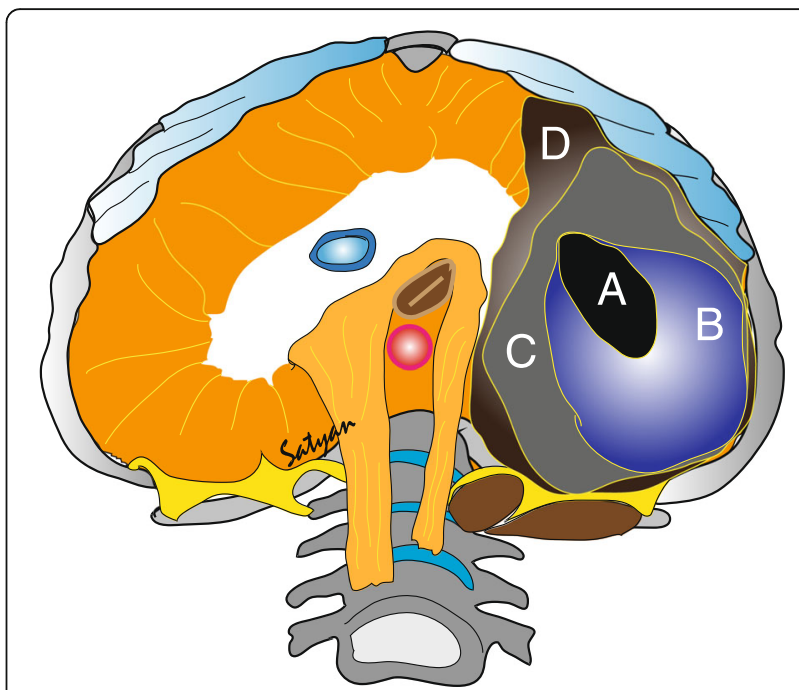

Fig. 2 Size of the defect - The size of the defect may vary between small (A) to diaphragmatic agenesis (D). Defects B \& C are considered moderate to large (Tsao et al. 2008). (Copyright Satyan Lakshminrusimha)

the extraembryonic coelom of the umbilicus. Another speculation is that lung hypoplasia may be the primary causal factor in the pathophysiology of diaphragmatic hernia [21]. If the development of lung bud is disturbed, there is an impaired development of a post hepatic mesenchymal plate (PHMP) that is closely related to the development of lung, resulting in a defective diaphragm [21]. Evidence from electron microscopy in a rat model [22] of $\mathrm{CDH}$ further supports the fact that when the development of the PHMP is impaired, a diaphragmatic defect occurs.

A weakness in the diaphragm can cause diaphragmatic eventration and may be mistaken for a diaphragmatic hernia. Diaphragmatic eventration is more common on the right side and is not associated with severe lung hypoplasia. While a complete absence of the diaphragm may occur resulting in diaphragmatic agenesis and severe lung hypoplasia. Irrespective of the basis, a defect in the diaphragm causes the abdominal viscera to herniate into the thoracic cavity resulting in abnormal lung development. The defect also leads to abnormal fetal breathing movements resulting in the void of stretchinduced lung maturation [16]. Thus the major underlying pathophysiology of $\mathrm{CDH}$ appears to be a combination of lung immaturity and hypoplasia that leads to PPHN. This may be further aggravated by left ventricular underdevelopment and right ventricular hypertrophy resulting in ventricular dysfunction [23-26].

\section{Lung hypoplasia/immaturity}

Lung hypoplasia occurs on the ipsilateral side of herniation, with the contralateral side being affected to a variable 
extent (Fig. 3). Hypoplasia was initially thought to be secondary to physical compression of the lung by abdominal contents arresting lung development. Recently, a two-hit hypothesis has been proposed based on rat model explaining the lung injury in $\mathrm{CDH}$ [27] (Fig. 4). According to this hypothesis, the initial insult occurs during the stages of organogenesis resulting in bilateral hypoplasia, followed by compression of the ipsilateral lung secondary to the herniation of the abdominal viscera at later stages. This theory explains the variability of lung hypoplasia on the contralateral side. The interference results in decreased branching of the bronchioles and pulmonary vessels leading to acinar hypoplasia $[28,29]$. The terminal bronchioles are decreased with thickening of alveolar septa. The lung is relatively immature [28] and hypoplasia of pulmonary vasculature leads to PPHN.

\section{Pulmonary hypertension in $\mathrm{CDH}$}

In $\mathrm{CDH}$, the total pulmonary vascular bed is reduced with decreased number of vessels per unit of lung. In addition, pulmonary vascular remodeling with medial hyperplasia and peripheral extension of the muscle layer into small arterioles is evident [30-32]. The paucity of pulmonary vasculature and remodeling of the vessels contribute to the 'fixed' or irreversible component of $\mathrm{PPHN}$ in $\mathrm{CDH}[33,34]$. Altered vasoreactivity possibly due to an imbalance of autonomic innervation (increased sympathetic and decreased parasympathetic)
[35], and/or impaired endothelium-dependent relaxation of pulmonary arteries [36, 37] or an imbalance between vasoconstrictor and vasodilator mediators may contribute to the reversible component of PPHN [35, 38]. Following birth, a combination of pulmonary arterial hypertension, right ventricular hypertrophy and/or failure, and left ventricular hypoplasia with pulmonary venous hypertension results in severe PPHN unresponsive to conventional management [39].

\section{Ventricular dysfunction}

Ventricular dysfunction is observed in some patients with severe PPHN due to $\mathrm{CDH}$. During fetal life, the ductus arteriosus serves as a pop-off value and limits right ventricular strain. After birth, remodeled pulmonary vasculature in $\mathrm{CDH}$ results in pulmonary hypertension and leads to right ventricle (RV) dysfunction. This is more pronounced after birth when there is excessive strain on the right ventricle. Abnormalities of the left ventricle (LV) have been reported in infants with $\mathrm{CDH}[26,40]$. When compared to neonates with other causes of PPHN, infants with left sided $\mathrm{CDH}$ had significantly lower left ventricular mass assessed by echocardiography. Reduced left ventricular output has been documented in left sided and right sided $\mathrm{CDH}$ [41]. The reduced left ventricular mass contributes to functional LV hypoplasia and may result in increased left atrial pressure and pulmonary venous hypertension (Fig. 5) [42].

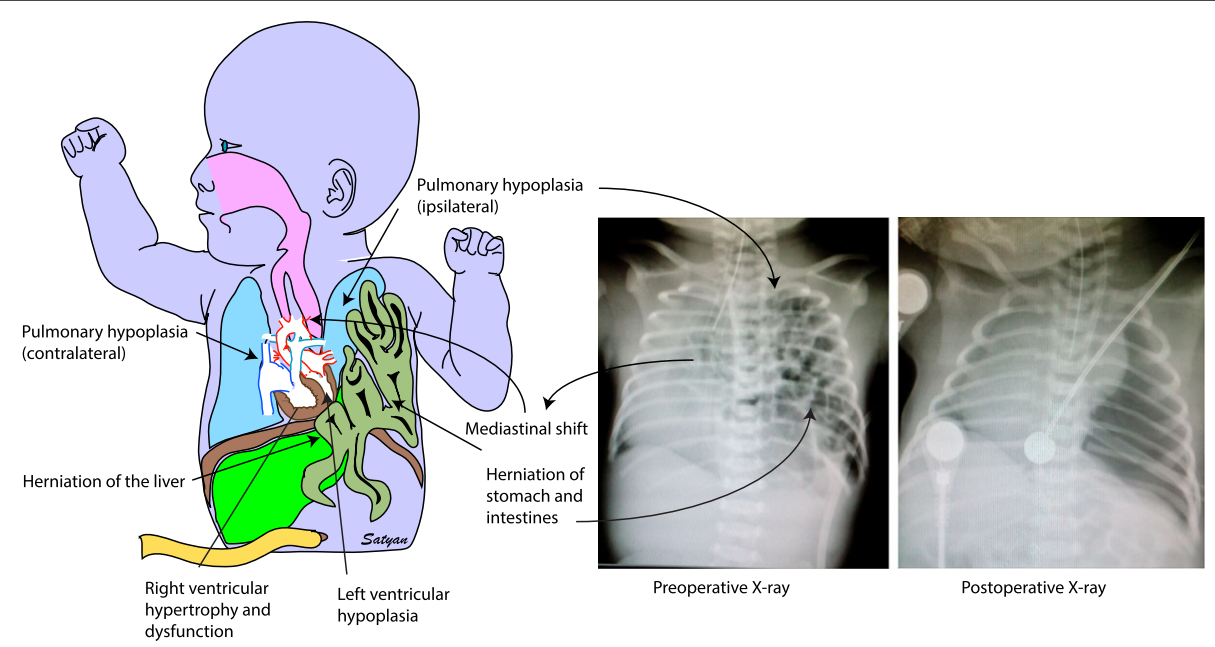

Fig. 3 Anatomical and radiological features of $\mathrm{CDH}$ - A defect in the diaphragm causes the abdominal viscera to herniate into the thoracic cavity. Left sided hernias are common (85\%) which results in herniation of both small and large intestines along with solid intra-abdominal organs. Herniation of viscera into the thoracic cavity results in abnormal lung development on the ipsilateral side with variable effect on the contralateral side. The effect of abnormal lung development on the contralateral side depends on the extent of herniation and the effect on mediastinal shift. Pulmonary hypoplasia results in abnormal pulmonary vasculature resulting in persistent pulmonary hypertension leading to right ventricular dysfunction. This is more pronounced after transitioning from fetal circulation. Left ventricular dysfunction can be secondary to direct compression in left sided hernia and secondary to low ventricular volumes in right sided hernias. Pre-operative chest and abdomen x-ray shows the air and fluid filled loops of bowels on the left side of the thorax with the endotracheal tube above the thoracic vertebra level 4 pushed towards the right side signifying mediastinal shift. (Copyright Satyan Lakshminrusimha) 


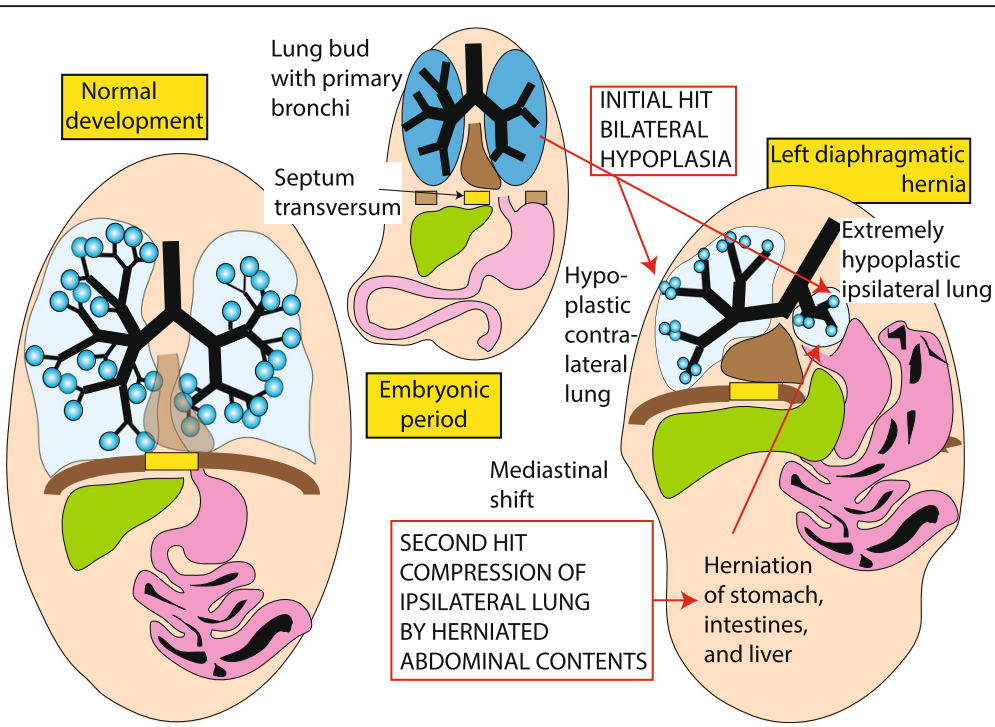

Fig. 4 Two-hit hypothesis for CDH (Copyright Satyan Lakshminrusimha)

\section{Diagnosis}

Prenatal diagnosis by ultrasound detects more than $50 \%$ of $\mathrm{CDH}$ cases at a mean gestational age of 24 weeks [43]. Three-dimensional ultrasound imaging, fetal echocardiography and fetal magnetic resonance imaging (MRI) are other prenatal diagnostic modalities used in assessing the severity and outcome of $\mathrm{CDH}$. Left sided $\mathrm{CDH}$ may be characterized by the presence of heterogeneous mass which may be stomach filled with fluid or intestines. In contrast, isolated right-sided $\mathrm{CDH}$ is extremely difficult to diagnose by ultrasound if the liver is the only organ that has herniated. Indirect signs such as a shift in cardiac axis, identifying the gall bladder and vasculature in the liver using Doppler may aide in the diagnosis [44]. MRI has been found to be useful in detecting fetal anomalies and can be a valuable adjunct to evaluate the position of the liver and estimating lung volume $[45,46]$. Associated cardiac and neural tube defects may affect the outcome of infants with $\mathrm{CDH}[47]$.

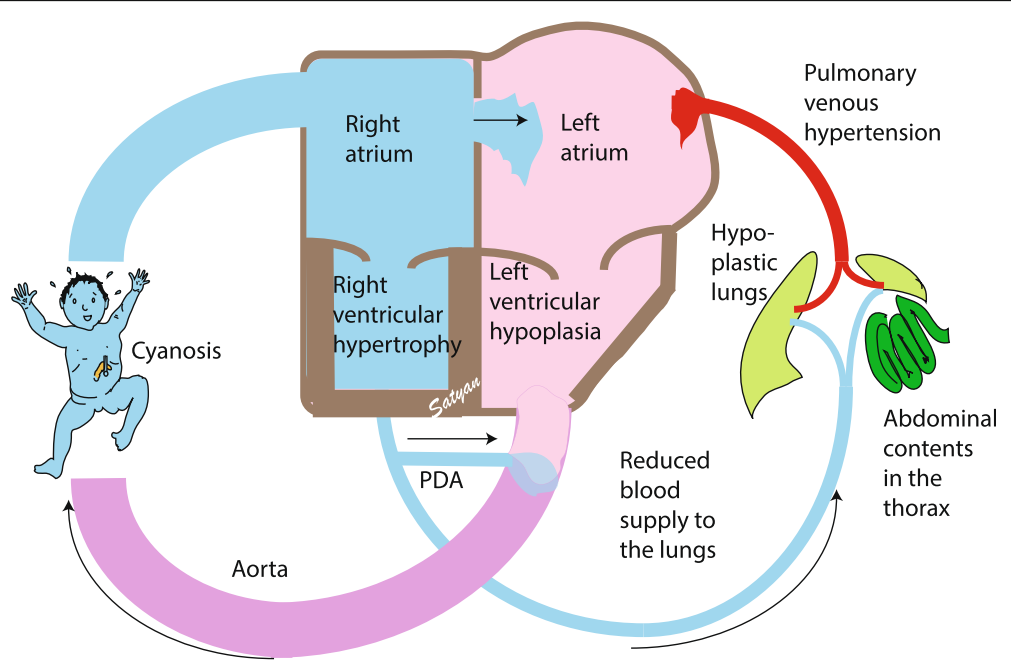

Fig. 5 Cardiovascular effects of $\mathrm{CDH}$ - Hypoplastic lungs secondary to herniation of abdominal viscera leads to concomitant hypoplasia of the pulmonary vessels. This results in reduced blood supply to the hypoplastic alveolar-capillary unit. Once the infant transitions from fetal circulation, this effect is more pronounced resulting in pulmonary hypertension which leads to right ventricular dysfunction. Secondary to pulmonary hypertension, there is shunting of blood from right to left across the patent foramen ovale and the patent ductus arteriosus. Left ventricular dysfunction along with left atrial dysfunction results in pulmonary venous hypertension and worsening of pulmonary arterial hypertension. This presents clinically in a wide spectrum of labile pre \& postductal saturations to profound cyanosis. (Copyright Satyan Lakshminrusimha) 


\section{Associated syndromes and anomalies requiring genetic work up}

Most common associated chromosomal abnormalities are the trisomies 18, 13 and 21 [48]. Chromosomal aneuploidies such as monosomy $\mathrm{X}$, tetrasomy $12 \mathrm{p}$, tetraploidy 21 have also been associated with $\mathrm{CDH}[43,48]$. $\mathrm{CDH}$ is the most common finding in Fryns syndrome [49]. $\mathrm{CDH}$ can also be part of Pentalogy of Cantrell, Apert, Brachmann-Cornelia De Lange, Beckwith-Wiedemann, CHARGE, Coffin-Siris, Goldenhar sequence, SimpsonGolabi-Behmel, Stickler, Pierre Robin sequence and VACTERL $[48,50]$.

Once diagnosed, the patient should be referred to a tertiary care center for further prenatal workup and management. A multi-disciplinary prenatal consult involving the obstetrics, neonatology, pediatric surgery, genetics at a center that has expertise in managing infants with $\mathrm{CDH}$ and extracorporeal membrane oxygenation (ECMO) are imperative. In addition, if an MRI was done, radiology is also involved in the multi-disciplinary prenatal consult.

\section{Fetal predictors of outcomes}

Major determinants of the outcomes in $\mathrm{CDH}$ are i) the presence of associated anomalies especially heart disease and ii) extent of lung hypoplasia and (iii) position of the liver [43].
The prognosis of isolated $\mathrm{CDH}$ is generally better than $\mathrm{CDH}$ complicated by multiple anomalies. Populationbased studies report higher survival for isolated $\mathrm{CDH}$ compared to $\mathrm{CDH}$ with anomalies $[4,51]$. Metkus et al. reported higher survival for $\mathrm{CDH}$ detected after 25 weeks by ultrasound [52]. This has not been validated and in the true sense, herniation that occurs before 25 weeks tends to have severe lung hypoplasia compared to herniation after 25 weeks [53].

Liver herniation (liver-up) is associated with worse prognosis. Earlier studies have reported $100 \%$ survival without liver herniation (liver-down) as compared to 56\% with liver herniation [52]. The survival decreased from 74 to $45 \%$ with liver herniation as reported by a meta-analysis [54]. In another study, liver herniation was highly predictive of ECMO (80\% - liver-up vs. 25\% - liver-down) and survival (45\% - liver-up vs. 93\% liver-down) [55].

Metkus et al. [52] used the ratio of the contralateral lung size compared with the head circumference to come up with the lung-to-head ratio (LHR, Fig. 6) to assess the severity of pulmonary hypoplasia and to predict postnatal outcome in fetuses with $\mathrm{CDH}[52,55,56]$. Since these measurements differed by gestational age and were not found to be consistent across centers [57, 58], observed to expected lung-to-head ratio (O/E LHR) was studied which was independent of gestational age [59]. LHR ratio

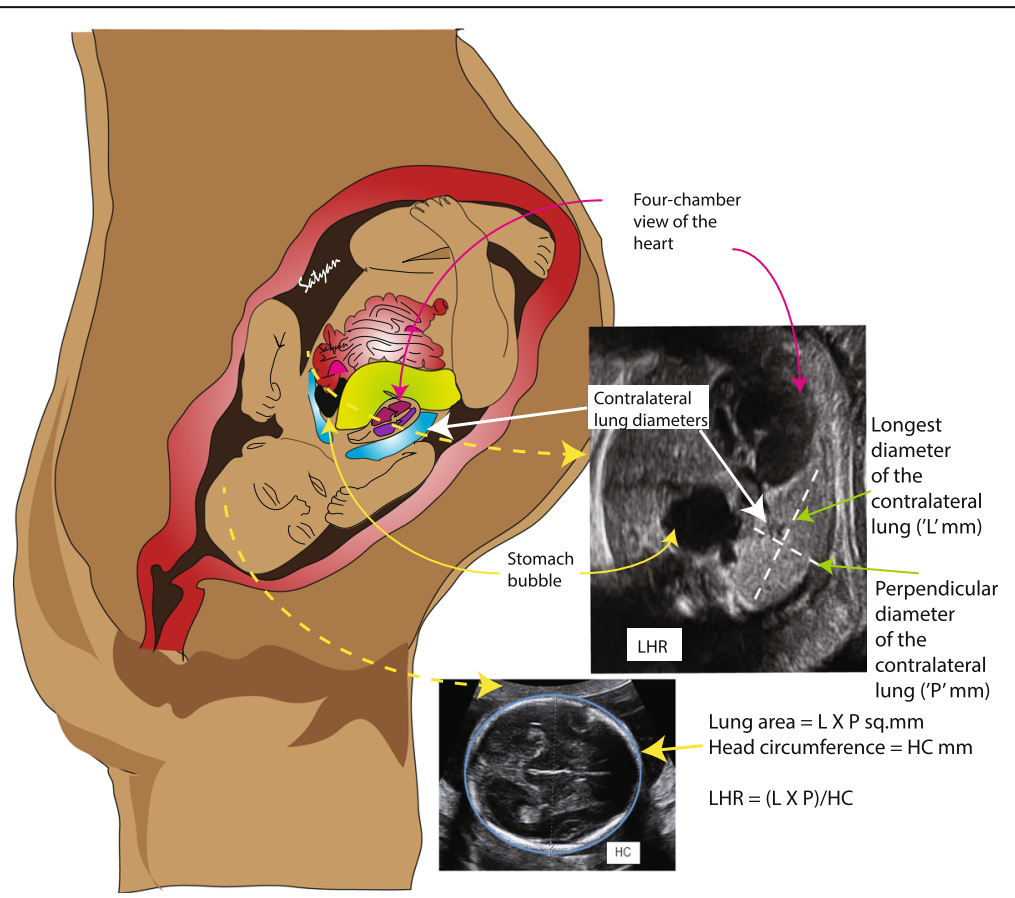

Fig. 6 Lung to head ratio (LHR) measurement - Obstetric ultrasound technique is used to measure the lung to head ratio known as LHR to assess the severity of $\mathrm{CDH}$. The head circumference is measured as shown. The contralateral lung area is calculated as a product of the longest and perpendicular diameter of the contralateral lung. The ratio of this area to the head circumference gives the LHR. A LHR of $<0.6$ has been associated with poor outcome while a ratio of $>1.35$ has been associated with survival. Alternatively, an observed to expected LHR measurement is used in order to overcome bias secondary to gestational age. (Copyright Satyan Lakshminrusimha) 
is often used along with liver herniation to predict outcome (see Table 1 below)

\section{Management}

\section{Antenatal Management - Medical}

Antenatal corticosteroids are administered to mothers in some centers to improve lung maturation in neonates with $\mathrm{CDH}$. While some animal results are promising [60], no significant advantages are reported in human infants [61]. It may be prudent to administer antenatal corticosteroids prior to delivery of preterm infants with $\mathrm{CDH}$ based on their premature gestation.

Pregnant rats with nitrofen induced $\mathrm{CDH}$ demonstrated significant improvement in lung structure, increased pulmonary vessel density, reduced right ventricular hypertrophy following antenatal therapy with high-dose sildenafil [36]. To our knowledge there are no human trials evaluating the role of antenatal phosphodiesterase inhibitors in $\mathrm{CDH}$.

\section{Antenatal Management - Surgical}

Tracheal occlusion: In the surgically induced lamb model of $\mathrm{CDH}$ with hypoplastic lungs, occlusion of the fetal trachea led to an acceleration of lung growth. Harrison et al. at the University of California in San Francisco (UCSF) reported the first randomized controlled trial of open hysterotomy-guided fetal endoscopic tracheal occlusion. No improvement in survival was observed when compared with conventional postnatal care. Junior et al. reported a meta-analysis of various fetoscopic tracheal occlusion studies. Fetoscopic tracheal occlusion procedure increased neonatal survival at 30 days and 6 months among patients with severe $\mathrm{CDH}$. However, it was associated with higher rate of premature rupture of membranes and decreased gestational age at delivery by 2 weeks [62]. A new minimally invasive

\section{Table 1 Antenatal ultrasound predictors of survival in $\mathrm{CDH}$}

A. LHR is calculated by dividing fetal lung area $\left(\mathrm{mm}^{2}\right)$ by fetal head circumference $(\mathrm{mm})$. Fetal lung area is usually measured at the level of the four-chamber view of the heart by multiplying the longest diameter of the contralateral lung by its longest perpendicular diameter. Alternatively, some obstetricians trace the lung margin and measure the lung area. The fetal head circumference is measured by its longest electronic ellipse.

a. LHR $>1.35$ associated with 100\% survival

b. LHR 1.35 to 0.6 associated with $61 \%$ survival

c. LHR $<0.6$ - no survival

B. Observed to expected LHR (O/E LHR) is calculated by dividing the observed LHR by the expected ratio for gestational age

a. The fetal lung area increases 16 -fold compared to 4 -fold increase in the head circumference between 12 and 32 weeks' gestation

b. O/E LHR $<25 \%$ is considered severe CDH (survival $10 \%$ with liver up and $25 \%$ with liver down)

c. O/E LHR $<15 \%$ with liver up $-100 \%$ mortality

C. Position of liver (or presence of liver herniation)

a. Liver herniation with LHR $<1.0-60 \%$ mortality

b. Liver in the thorax $-56 \%$ survival; operation termed percutaneous fetal endoluminal tracheal occlusion (FETO) is being subjected to randomized clinical trials with ongoing recruitment. More information about FETO can be found at http://www.chop.edu/centers-programs/center-fetal-diagnosis-and-treatment/fetoscopic-end oluminal-tracheal-occlusion-feto or http://childrens.memo rialhermann.org/FETO-trial/.

\section{The timing of delivery}

The optimal timing of delivery of an infant with $\mathrm{CDH}$ is controversial. Stevens et al. initially reported that among infants delivered by elective cesarean section, early term birth (at 37-38 weeks gestation) was associated with less use of ECMO (22 vs. 35.5\%) compared to term delivery (at 39-41 weeks) [63]. However, more recent analysis suggested decreased mortality with advancing gestation [64]. Among 928 infants with $\mathrm{CDH}$ in this review, neonatal and infant mortality decreased from 25 and $36 \%$ respectively at 37 weeks gestation to 17 and $20 \%$ at 40 weeks gestation. We recommend delivery after completion of 39 weeks of gestation to avoid complications associated with prematurity and early term delivery [65].

\section{Postnatal Management - Medical (Fig. 7)}

Delivery room (DR) Deliveries should be conducted at centers with capabilities of managing an infant with $\mathrm{CDH}$ and associated complications. Resuscitation in the DR is based on neonatal resuscitation program (NRP) guidelines [66]. All infants with $\mathrm{CDH}$ or suspected $\mathrm{CDH}$ need an orogastric/nasogastric tube with suction to decompress the bowel. Bag-mask ventilation should be avoided. The majority of these infants (especially with a prenatal diagnosis of $\mathrm{CDH}$ ) require intubation in the delivery room. A pre-ductal pulse oximeter is placed on the right upper extremity as soon as possible. Ventilation using a T-piece resuscitator is preferred to avoid high airway pressures. Peak inspiratory pressure (PIP) should be preferably below $25 \mathrm{~cm} \mathrm{H}_{2} \mathrm{O}$ to avoid damage to the hypoplastic/immature lung. Oxygen can be titrated to maintain preductal saturations recommended by NRP. In some institutions, preductal saturations $>70 \%$ are accepted for the first $1-2 \mathrm{~h}$ if $\mathrm{pH}$ and arterial carbon dioxide for $\mathrm{PaCO}_{2}$ are within normal limits.

Stabilization Central or peripheral venous access is obtained for administering fluids and medications. An arterial line for monitoring blood pressure and to draw blood gases is needed. Although it has been traditional to place an umbilical arterial line, it may be preferable to obtain a preductal arterial line in the right radial or ulnar artery. Umbilical artery line values reflect postductal arterial oxygen tension $\left(\mathrm{PaO}_{2}\right)$ and lead to increased fraction of inspired oxygen $\left(\mathrm{FIO}_{2}\right)$. Systemic blood pressures are maintained at normal values for gestational age 


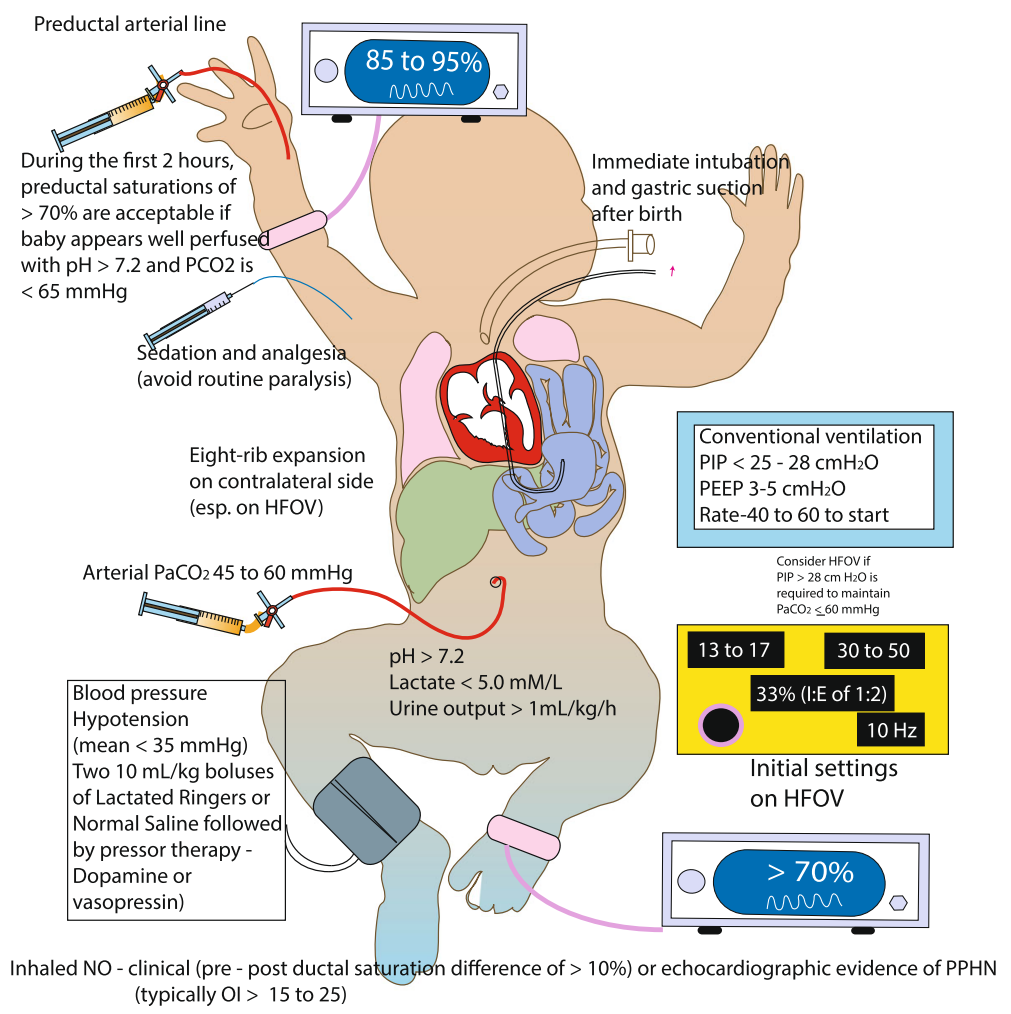

Fig. 7 Management of $\mathrm{CDH}$ - At birth infants with $\mathrm{CDH}$ or suspected $\mathrm{CDH}$ should have an orogastric/nasogastric tube with suction to attain bowel decompression. Bag-mask ventilation should be avoided. The majority of these infants (especially with prenatal diagnosis of $\mathrm{CDH}$ ) require intubation in the delivery room. A pre-ductal pulse oximeter is placed on the right upper extremity as soon as possible. Oxygen saturation targets are based on NRP guidelines. Ventilation using a T-piece resuscitator is preferred to avoid high airway pressures. Ventilator parameters are as shown in the figure. Preductal blood gases and invasive blood pressure monitoring are preferred. Inhaled nitric oxide is often used for the management of PPHN. For blood pressure management, fluid boluses and vasopressor agents are used based on the parameters in the figure. (Copyright Satyan Lakshminrusimha)

[67]. Pre-ductal saturations are maintained between $85-$ $95 \%$. A chest $\mathrm{x}$-ray is obtained to assess the initial condition of the lung and herniated content.

Mechanical Ventilation The optimal ventilation mode for infants with $\mathrm{CDH}$ and hypoplastic lungs is not known. Many centers initiate conventional mechanical ventilation (CMV) for respiratory support and optimize ventilation by adjusting PIP and respiratory rate. The recently concluded VICI (Ventilation in infants with congenital diaphragmatic hernia) trial compared CMV and high-frequency oscillatory ventilation (HFOV) as the initial mode of ventilation in $\mathrm{CDH}$. There was no statistically significant difference in the combined outcome of mortality or bronchopulmonary dysplasia (BPD) [68]. In this study, 91 (53.2\%) patients initially received CMV and 80 (46.8\%) HFOV. Forty-one patients (45.1\%) randomized to CMV died/had BPD compared with 43 patients (53.8\%) in the HFOV group. An odds ratio of 0.62 [95\% confidence interval $(95 \% \mathrm{CI}) 0.25-1.55](P=$ 0.31) for death/BPD for CMV vs HFOV was demonstrated, after adjustment for center, LHR, side of the defect, and liver position. Patients initially ventilated by CMV were ventilated for fewer days $(P=0.03)$, less often needed ECMO support $(P=0.007)$, inhaled nitric oxide (iNO, $P=0.045)$, sildenafil $(P=0.004)$, had a shorter duration of vasoactive drugs $(P=0.02)$, and less often failed treatment $(P=0.01)$ as compared with infants initially ventilated by HFOV. It is important to note that guidelines for initial settings for CMV in this study included low positive end-expiratory pressure (PEEP) ( 3 to $5 \mathrm{~cm} \mathrm{H}_{2} \mathrm{O}$ ) and PIP (20 to $25 \mathrm{~cm}$ $\mathrm{H}_{2} \mathrm{O}$ ). These findings suggest that an initial attempt at $\mathrm{CMV}$ is reasonable for patients with $\mathrm{CDH}$.

A review of autopsies of 68 infants with $\mathrm{CDH}$ showed significant pulmonary injury (alveolar damage, hyaline membrane formation, pneumothoraces in $2 / 3$ of autopsies) secondary to mechanical ventilation where 53 infants were switched to HFOV in a median time of $15 \mathrm{~h}$ from birth [69]. In view of preventing volutrauma and barotrauma, a gentler approach to ventilation is preferred in infants with $\mathrm{CDH}$. CMV mode [70, 71] with 
PIP usually below $25 \mathrm{~cm} \mathrm{H}_{2} \mathrm{O}$ and PEEP $\leq 5 \mathrm{~cm} \mathrm{H}_{2} \mathrm{O}$ targeting preductal saturations of $>85 \%$, post-ductal saturations of $>70 \%$ and $\mathrm{PaCO}_{2}$ of $45-60 \mathrm{mmHg}$ are used to initiate ventilation. Many centers switch to HFOV or jet ventilation as a rescue therapy if the ventilator targets cannot be achieved on CMV. The settings on HFOV are not well defined. Mean airway pressure (MAP) is usually adjusted to maintain adequate inflation of the contralateral lung to 8 ribs in a range of $13-17 \mathrm{~cm} \mathrm{H}_{2} \mathrm{O}$ [71-73].

The role of surfactant Although animal studies strongly suggest the presence of an immature lung with surfactant deficiency, a retrospective analysis failed to support any beneficial effect of surfactant replacement therapy in term infants with $\mathrm{CDH}$ [74]. Its use in preterm infant was also associated with lower survival rate [75]. However, this trial by its retrospective nature may be biased as sicker patients may have received surfactant Although there are no increasing trends in use of surfactant, it is still being used in preterm infants with $\mathrm{CDH}$ across centers [76]. Prospective trials are needed to evaluate the benefits of surfactant in infants with $\mathrm{CDH}$. The beneficial effect of surfactant cannot be ruled out in a premature lung and it is unclear if there is a direct causal association between surfactant administration and mortality in infants with $\mathrm{CDH}$.

Hemodynamic monitoring and management Invasive blood pressure (BP) monitoring is preferred over noninvasive monitoring. Pre and post-ductal saturations and heart rate should be continuously monitored. Optimal end-organ perfusion is the goal to hemodynamic monitoring in infants with $\mathrm{CDH}$. Signs of adequate perfusion include normal range of heart rate for gestational age, normal capillary refill, a urine output $>1.0 \mathrm{ml} / \mathrm{kg} / \mathrm{h}$, arterial $\mathrm{pH}>7.2$ and lactate levels of $<3-5 \mathrm{mmol} / \mathrm{L}$ [71]. If there are signs suggestive of poor perfusion, volume resuscitation and vasopressor therapy should be considered. The treatment should be streamlined based on cardiac function assessed by echocardiogram and volume requirement. In case of hypovolemia, a bolus with an isotonic solution like $0.9 \%$ normal saline or lactated Ringer's solution, $10 \mathrm{ml} / \mathrm{kg}$ intravenously can be given. Volume resuscitation is usually followed by vasopressor/ inotropic therapy.

\section{Vasopressor/inotropic therapy (Table 2)}

Dopamine is the most commonly used cardiovascular medication in NICU and is given as an infusion [77] aiming to maintain systemic BP appropriate for gestational age. Dobutamine is preferred in infants with poor myocardial contractility. Norepinephrine and epinephrine may be used as first line agents in some institutions secondary to their potent vasoconstrictor activity. Epinephrine infusion can falsely increase the lactate levels and can interfere with management [77]. Low-dose hydrocortisone is beneficial in vasopressor-resistant hypotension in the immediate postnatal period [78]. Vasopressin was reported to be effective in stabilizing systemic hemodynamics in a retrospective chart review with decreased pulmonary/systemic pressure ratio, in patients with $\mathrm{CDH}[79]$.

Management of pulmonary hypertension (Fig. 8) PPHN in CDH infants is secondary to hypoplastic lungs and pruned, remodeled vasculature [39, 80]. Pulmonary arterial hypertension along with left ventricular hypoplasia and right ventricular hypertrophy and/or failure complicated by pulmonary venous hypertension results in severe PPHN not responsive to conventional therapy. Due to right to left shunting, pre and postductal saturation difference may be observed. The absence of a difference does not rule out pulmonary hypertension. In some patients with $\mathrm{CDH}$ the immediate postnatal phase, there is a short period of better oxygenation referred to as "honeymoon" period [39]. However, progressive deterioration in oxygenation is commonly observed with deteriorating PPHN. An echocardiogram is the best non-invasive test to assess cardiac function and pulmonary pressures in an infant with $\mathrm{CDH}$ and is usually done within the first $24 \mathrm{~h}$ and followed up as needed [81].

If preductal saturations decreases below $85 \%$, ventilation adjustments and hemodynamic management take precedence prior to initiating any therapy. Measures to increase systemic blood pressure may minimize the right-to-left shunting. However, there is no need to increase blood pressure to supranormal values if preductal saturation remains above $80 \%$. Catecholamines, especially dopamine, besides increasing systemic vascular resistance also increases pulmonary vascular resistance $[30,82]$. The $\mathrm{CDH}$ consortium recommends maintaining arterial blood pressure at normal levels for gestational age if preductal saturations are between 80 to $95 \%$ [83].

Inhaled Nitric Oxide (iNO) is the first agent of choice for treatment of pulmonary hypertension in infants $>34$ weeks' gestation. It is a selective pulmonary vasodilator and relaxes pulmonary vascular smooth muscle cells. The criteria for initiating iNO is based on the severity of PPHN as assessed by the oxygenation index $(\mathrm{OI})$. (Note: oxygenation index $(\mathrm{OI})$, = Mean airway pressure $\times \mathrm{FiO}_{2}$ × $100 \div \mathrm{PaO}_{2}$ ). Oxygen saturation index (OSI) is a non-invasive means of estimating oxygenation status and can be used in the absence of an arterial blood gas but requires further validation $[84,85]$. It is calculated using the following formula: Oxygen saturation index $(\mathrm{OSI})=$ Mean airway pressure $\mathrm{x} \mathrm{FiO}_{2} \times 100$ $\div$ preductal $\mathrm{SpO}_{2}$ ). Studies in the past have reported a mean OI of $25 \pm 9$ as the cut off for initiation of iNO [86]. Currently, in neonates with PPHN not due to 
Table 2 Vasoactive medications commonly used in CDH: Typical doses, route of administration of inotropic and vasodilator medications in the management of $\mathrm{CDH}$

\begin{tabular}{|c|c|c|c|c|}
\hline Drug & Route & Units & Initial dose & Maintenance Dose range \\
\hline DOPAmine & IV & $\mu \mathrm{g} / \mathrm{kg} / \mathrm{min}$ & 1 to 5 & 1 to 50 (usually 2.5 to 20 ) \\
\hline DOBUTamine & IV & $\mu \mathrm{g} / \mathrm{kg} / \mathrm{min}$ & 1 to 5 & 1 to 40 (usually 2.5 to 20 ) \\
\hline EPInephrine & IV & $\mu \mathrm{g} / \mathrm{kg} / \mathrm{min}$ & 0.05 to 0.1 & 0.1 to 1 \\
\hline NOREPInephrine & IV & $\mu \mathrm{g} / \mathrm{kg} / \mathrm{min}$ & 0.05 to 0.1 & 0.05 to 2 \\
\hline PGE1 - Alprostadil & IV & $\mu \mathrm{g} / \mathrm{kg} / \mathrm{min}$ & 0.05 to 0.1 & 0.01 to 4 \\
\hline PGE1 - Alprostadil & Inhaled & $\mu \mathrm{g} / \mathrm{kg} / \mathrm{min}$ & 0.15 to 0.3 & 0.15 to 0.3 \\
\hline Milrinone & IV & $\mu \mathrm{g} / \mathrm{kg} / \mathrm{min}$ & 0.25 to 0.75 (some units use a load of $50 \mu \mathrm{g} / \mathrm{kg}$ ) & 0.25 to 1 \\
\hline Dexamethasone & IV & $\mathrm{mg} / \mathrm{kg} / \mathrm{dose}$ & 0.05 to 0.6 & 0.05 to 0.6 \\
\hline Hydrocortisone & IV & $\mathrm{mg} / \mathrm{kg} / \mathrm{dose}$ & 1 to 5 & 0.5 to 5 \\
\hline Nitric oxide (NO) & Inhaled & Ppm & 5 to 20 & 1 to 80 \\
\hline Vasopressin & IV & Units $/ \mathrm{kg} / \mathrm{min}$ & 0.0001 to 0.002 & 0.0001 to 0.008 \\
\hline Prostacyclin (Epoprostenol - Flolan) & IV & $\mathrm{ng} / \mathrm{kg} / \mathrm{min}$ & 1 to 3 & 50 to 80 \\
\hline Prostacyclin (Epoprostenol - Flolan) & Inhaled & $\mathrm{ng} / \mathrm{kg} / \mathrm{min}$ & 50 & 25 to 50 \\
\hline Prostacyclin (Treprostinil - Remodulin) & SQ or IV & $\mathrm{ng} / \mathrm{kg} / \mathrm{min}$ & 1.25 to 2 & 50 to 80 \\
\hline Prostacyclin (Treprostinil - Remodulin) & Inhaled & $\mu \mathrm{g} / \mathrm{breath}$ & 6 & \\
\hline Prostacyclin (lloprost) & Inhaled & $\mu \mathrm{g} / \mathrm{breath}$ & 2.5 or 5 & \\
\hline Prostacyclin (Beraprost) & $\mathrm{PO}$ & $\mu \mathrm{g}$ & 80 & 80 to 120 (adult dose) \\
\hline Sildenafil & IV & $\mathrm{mg} / \mathrm{kg} / \mathrm{h}$ & 0.14 for $3 \mathrm{~h}$ & 0.07 \\
\hline Bosentan & PO & $\mathrm{mg} / \mathrm{kg} /$ dose & 1 to 2 & 1 to 2 \\
\hline
\end{tabular}

$\mathrm{CDH}$, it is acceptable to start iNO with an OI of $\geq 20$ and evidence of right-to-left shunting by clinical exam (a pre postductal saturation difference of $\geq 10 \%$ ) [71] [87] [80] and/or echocardiographic evidence of extrapulmonary right to left shunting [88]. The typical initial dose is 20 parts per million (ppm) [89] although variable dosing has been mentioned in the literature. A complete response to iNO is considered to be an increase in the ratio of arterial oxygen tension $\left(\mathrm{PaO}_{2}\right)$ to fraction of inspired oxygen $\left(\mathrm{FiO}_{2}\right)$ by $\geq 20 \mathrm{mmHg}$ post iNO therapy [80].

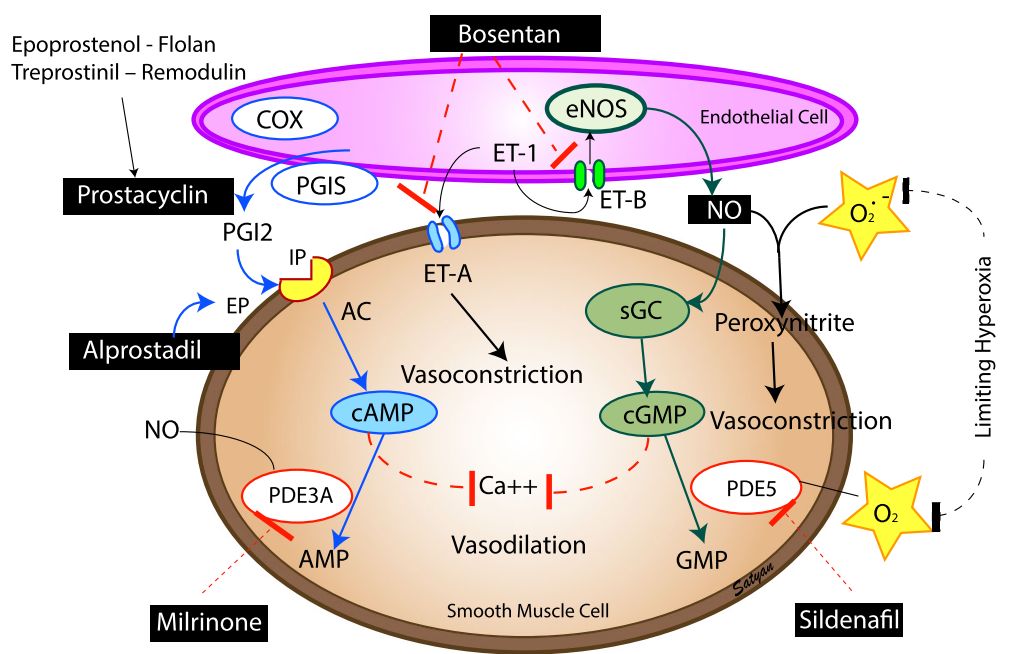

Fig. 8 Management of pulmonary hypertension in CDH: pulmonary vasodilators and nitric oxide - prostacyclin - endothelin pathways. AC acetylcholine, Ca- calcium, CAMP - cyclic adenosine monophosphate, cGMP - cyclic guanosine monophosphate, COX - cycloxygenase, eNOS endothelial nitric oxide synthase, ET - endothelin, EP - prostaglandin E receptor, IP - prostacyclin I receptor, NO - nitric oxide, PGI prostaglandin I, SGC - soluble guanylyl cyclase, PDE - phosphodiesterase inhibitor (Copyright Satyan Lakshminrusimha) 
In contrast to PPHN from conditions other than $\mathrm{CDH}$, iNO did not reduce the need for ECMO or death in a prospective, randomized trial in infants with $\mathrm{CDH}$ [90]. The ventilation approach, choice of ventilator and the $\mathrm{OI}$ at enrollment in this study were different from current practice [33]. In spite of this negative study, iNO continues to be used in US tertiary centers in the management of infants with $\mathrm{CDH}$ without a change in ECMO utilization or mortality [91]. If there is no response to iNO after optimizing ventilation and hemodynamic status, iNO is gradually weaned. Some patients decompensate and become hypoxemic with discontinuation of iNO. In these instances, iNO is weaned to a low dose for a few hours and then discontinued.

The rationale for continuing vs. weaning off iNO when there is no response is unclear. Continuing iNO with high oxygen could be detrimental. Nitric oxide is a free radical and can combine with superoxide anions to form peroxynitrite, which is a toxic vasoconstrictor. Thus, continuing iNO therapy in the absence of response remains controversial.

Infants with corrected $\mathrm{CDH}$ are at risk for late pulmonary hypertension. Inhaled nitric oxide may play an important role in treating exacerbations of pulmonary hypertension in these patients [88] [92, 93].

Prostaglandin (PGE1) intravenous (IV) PGE1 has been used in infants with $\mathrm{CDH}$ especially in the setting of right heart failure [94]. A trial of PGE1 to reopen the ductus may reduce the load on the right ventricle. Some groups have suggested starting PGE1 infusion when the duration of right-to-left shunting through the ductus arteriosus was longer than left to right shunting [95]. In patients with ductal-dependent critical congenital heart disease associated with CDH, IV PGE1 is necessary to maintain ductal patency. Inhalational PGE1 is also used as an alternative agent in treating PPHN in infants with $\mathrm{CDH}$ [96]. These are non-FDA approved therapies and lack evidence.

Prostacyclin $\left(\mathrm{PGI}_{2}\right)$ is commonly used in adults may be useful in the management of late pulmonary hypertension in infants post $\mathrm{CDH}$ repair. Currently, there is no evidence to support this therapy but some centers use it as a second-line pulmonary vasodilator. Prostacyclin can be used as an inhaled agent or an intravenous agent. Three forms of prostacyclin are used in the management of pulmonary hypertension (Table 2). Epoprostenol (Flolan), Treprostinil (Remodulin) and inhaled Iloprost (Ventavis - inhaled prostacyclin analog) are approved for adults with pulmonary arterial hypertension.

Sildenafil is a phosphodiesterase (PDE) 5 inhibitor that inhibits cyclic guanosine monophosphate (cGMP) degradation leading to vasodilation. Oral sildenafil improves oxygenation and reduces mortality in PPHN in centers limited by non-availability of iNO and ECMO [97, 98].
IV sildenafil was shown to be effective in improving oxygenation in patients with PPHN with and without prior exposure to iNO [99]. There are no trials to support its use in infants with $\mathrm{CDH}$. A chronic sildenafil trial was planned in $\mathrm{CDH}$ infants but is currently terminated and not recruiting patients (NCT00133679). As per FDA, high mortality is associated with its use in pediatric patients (1-17 y of age) with pulmonary arterial hypertension [100]. Parents should be informed about the benefits and side-effects of sildenafil prior to initiation for chronic use in $\mathrm{CDH}$.

Milrinone is a PDE 3 inhibitor which increases cyclic adenosine monophosphate (cAMP) concentration in smooth muscle and myocardium. It has both lusitropic and inotropic properties. In a fetal lamb model of PPHN, milrinone relaxed pulmonary arteries [101] and reduced pulmonary arterial pressure. The benefits of milrinone in children following surgery for congenital heart disease have been well established [102]. Multiple case series have shown IV milrinone to be effective in treating infants with iNO resistant PPHN [103, 104-106]. Milrinone therapy has been used in the management of iNO resistant PPHN in infants with $\mathrm{CDH}$. Hypotension is a clinical concern and the infants should be monitored closely. Despite lack of evidence, the use of milrinone in the management of infants with $\mathrm{CDH}$ has increased [76]. A loading dose (50 $\mu \mathrm{g} / \mathrm{kg}$ for 30-60 $\mathrm{min})$ followed by a maintenance dose $(0.33 \mu \mathrm{g} / \mathrm{kg}$ per minute and escalation to 0.66 and then to $1 \mu \mathrm{g} / \mathrm{kg}$ per minute based on response) are commonly used. The loading dose of milrinone will increase the risk of hypotension but may achieve steady state plasma levels sooner [107]. Hence, the loading dose is not recommended in the presence of systemic hypotension in patients with $\mathrm{CDH}$ [108]. Some clinicians administer a volume bolus prior to the loading dose of milrinone to avoid systemic hypotension.

A multicenter trial investigating the use of milrinone in infants with $\mathrm{CDH}$ has been proposed by the NICHD Neonatal Research Network and will begin enrollment shortly (NCT02951130).

Bosentan is a blocker of endothelin receptors and is occasionally used as an oral agent in the management of chronic pulmonary hypertension in $\mathrm{CDH}$. There is limited experience with its use in neonates [109]. Liver function tests should be closely followed during its use.

Extracorporeal membranous oxygenation (ECMO) is considered as the last lifesaving option for infants $\geq$ 34 weeks' gestation or with weight $>2 \mathrm{~kg}$ with $\mathrm{CDH}$ and no associated major lethal anomalies after conventional medical management has failed. Strong evidence for ECMO is lacking although the number of infants with $\mathrm{CDH}$ who undergo ECMO treatment has not decreased. Selection criteria for ECMO varies across centers and remains controversial. The Euro consortium experts have 
published criteria [71] for ECMO. There is considerable institutional variability but the following approach seems reasonable - (a) Inability to maintain preductal saturations $>85 \%$ or postductal saturations $>70 \%$ along with (b) increased $\mathrm{PaCO}_{2}$ and respiratory acidosis with $\mathrm{pH}<7.15$ despite optimal ventilator management, (c) PIP of $>28 \mathrm{~cm}$ $\mathrm{H}_{2} \mathrm{O}$ or MAP $>17 \mathrm{~cm} \mathrm{H}_{2} \mathrm{O}$ to achieve saturations $>85 \%$, (d) inadequate oxygen delivery with metabolic acidosis, (e) systemic hypotension resistant to fluid and pressor therapy resulting in urine output $<0.5 \mathrm{ml} / \mathrm{kg} / \mathrm{h}$ for a $12-24 \mathrm{~h}$ period and (f) consistently elevated $\mathrm{OI} \geq 40$.

Venoarterial (VA) ECMO is preferred in the presence of cardiovascular compromise. There is a shift towards increased use of venovenous (VV) ECMO in patients with $\mathrm{CDH}$ and has comparable mortality rates $[110,111]$. Functionally VA ECMO has the advantage of decreasing the load on the right side of the heart. However, VV ECMO allows oxygenated blood to flow through pulmonary circulation resulting in enhanced pulmonary vasodilation while preserving the carotid arteries. In addition, maintaining pulsatile flow with oxygenated blood may improve coronary perfusion and cardiac function with $\mathrm{VV}$ ECMO. Failure of VV ECMO and a switch to VA ECMO may be required in some patients.

Duration of treatment on ECMO is a subject of debate. Congenital Diaphragmatic Hernia Study Group retrospective data from 1995-2004 showed increased survival in infants treated for 9 days compared to 14 days [112]. A single institution 19-year retrospective review concluded that in patients with severe $\mathrm{CDH}$, improvement in pulmonary function sufficient to wean from ECMO can take 4 weeks or longer and might need a second ECMO run [113]. The study reported survival rates based on the duration of ECMO run as 56\% for 2 weeks, $46 \%$ for 3 weeks, $43 \%$ for 4 weeks after which the survival dropped to $15 \% .44 \%(7 / 16)$ of infants who were treated on the second run of ECMO survived. ELSO registry data [112] shows an increase in mortality for ECMO duration $>2$ weeks. Prolonged duration of ECMO is a predictor of mortality $[112,114]$.

\section{Postnatal management - Surgical}

When considering repair of the $\mathrm{CDH}$, the surgeon faces three questions: a) what is the benefit; $b$ ) when is the optimal time; and c) what is the best approach? The first question, although philosophical, is critical. Our understanding of the benefits of repair are incomplete, but most literature supports the idea that reduction of the herniated visceral contents from the thoracic cavity and closure of the diaphragmatic defect are important in the long-term but provide little immediate benefit to the patient [115]. Reducing herniated contents back to the abdomen to permit expansion of the compressed lungs does not result in immediate improvement in PPHN and hypoxemia. Pulmonary hypertension is, however, the "rate-limiting" disease process in $\mathrm{CDH}$ and rarely does hernia reduction/repair significantly improve outcome by itself. This is particularly important as the surgical stress of operation is often severe enough to induce pulmonary hypertensive crises in the sicker patients, and if undertaken in a patient while on ECMO, can lead to severe hemorrhagic complications.

Optimal timing of $\mathrm{CDH}$ repair can be difficult to determine, particularly in patients who require ECMO. For those patients not requiring ECMO, repair is usually offered no sooner than $48-72 \mathrm{~h}$ after birth, with the assumption that these patients' pulmonary vasculature is not so compromised as to pose a significant risk of perior postoperative decompensation. Once a patient requires ECMO, the decision process becomes more difficult. There are generally three approaches: early repair, immediately after ECMO initiation (typically $<72 \mathrm{~h}$ ); delayed repair, often done as a last-hope operation in the setting of inability to wean off ECMO; and repair after decannulation [116]. The data on the influence of timing of repair on outcomes are hampered by limited numbers, retrospective design, patient group heterogeneity, and thus do not serve well to inform the decision in a generalizable and reliable manner. In broad strokes, best outcomes appear to be in patients repaired after decannulation (technically, these may be repaired the day prior to anticipated decannulation, but in a patient who has improved while on ECMO). Following this, those patients repaired shortly after cannulation do better than those repaired after several weeks on ECMO. Improvements in the medical treatment and prevention of bleeding diatheses while on ECMO, and improved ECMO circuits, have helped to mitigate some of the lethal bleeding complications of repair on ECMO.

\section{Surgical approach}

Repair of the CDH may be accomplished through a thoracic or abdominal approach, and may be performed in an open or minimally invasive manner. Long-term outcomes depend, perhaps most importantly, on the characteristics of the diaphragmatic defect. Patients with a small muscular defect that is easily approximated primarily should have negligible recurrence rates and complications. There has been an increasing trend toward thoracoscopic repairs, which are thought to minimize post-operative pain and scarring and hasten recovery. Several series have demonstrated higher recurrences rates through the thoracoscopic approach, although these may have been biased by higher rates of unfavorable anatomy and an inherent learning curve [117]. Patients at the other end of the spectrum, with diaphragmatic agenesis, uniformly require placement of a patch to close the diaphragmatic defect (Fig. 9a \& b). These are typically made of synthetic 


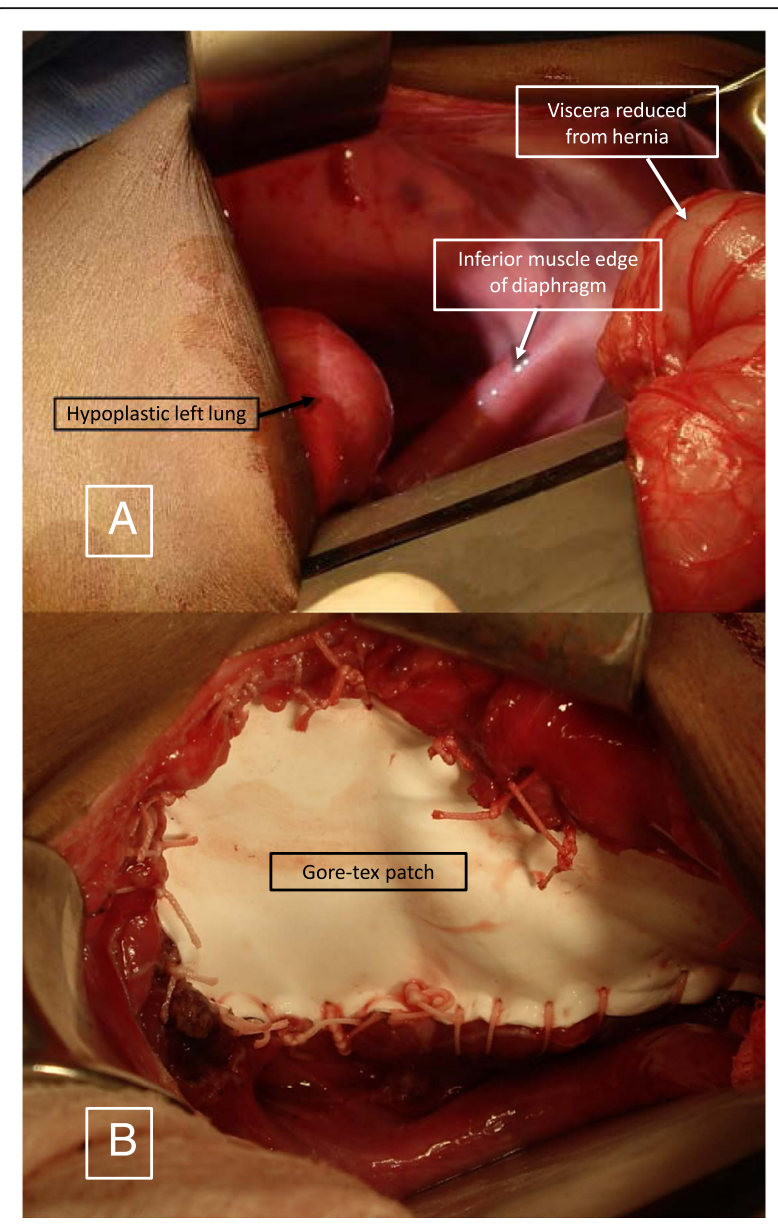

Fig. 9 a Left sided diaphragmatic hernia showing the hypoplastic left lung, inferior muscle edge of the diaphragm and reduced viscera. b Prosthetic patch - Gore-Tex patch used to close the defect

materials (Goretex ${ }^{\oplus}$ is most popular) but there has been growing recent interest in combining synthetic materials with additional biologic layers in an effort to buttress the repair and promote native tissue ingrowth for long-term stability [118]. Lastly, several groups have lauded the benefits of autologous, muscle flap closure of the defect [119].

\section{Follow-up and outcomes}

Infants with $\mathrm{CDH}$ face considerable long-term respiratory issues, nutritional problems, neurodevelopmental delays, hernia recurrence and orthopedic deformities [120]. The American Academy of Pediatrics (AAP) came out with guidelines for follow-up of infants who are discharged with $\mathrm{CDH}$ [120]. A multidisciplinary approach with long-term follow-up is required for these infants.

Respiratory morbidities include chronic lung disease, rebound pulmonary hypertension, obstructive pulmonary disease and infection. Treatment with ECMO and patch repair were associated with more significant pulmonary morbidity [121] with decreased inspiratory muscle strength.
Adolescent survivors often-faced mild to moderate obstructive disease requiring bronchodilator therapy along with weak inspiratory muscle strength [122]. Nutritional problems include gastro esophageal reflux [123, 124] aversion to oral feeds, gastrostomy tube feeding and failure to thrive. Neurological and development problems range from physical disability to neurocognitive and functional delays. Hearing loss is common in these infants $[125,126]$. Orthopedic deformities such as pectus and scoliosis are seen in patients post CDH repair [122, 127].

\section{Conclusion}

Despite the unclear etiology of $\mathrm{CDH}$ and management of PPHN, over the past few decades, reports have suggested increasing trends of survival in infants with $\mathrm{CDH}$ [76]. With the medical and surgical advances in the management of $\mathrm{CDH}$, the reported overall survival is 70-90\% [7, $76,128]$. With ECMO, the survival is around 50\% [112114 ] with different centers reporting different criteria and outcomes. Multiple factors such as prematurity, ECMO, associated abnormalities especially cardiac, need for transport, severity of PPHN, type of repair can affect the outcome and survival of an infant with $\mathrm{CDH}[51,114,128$, 129].

\section{Abbreviations}

$\mathrm{CDH}$ : Congenital Diaphragmatic hernia; CMV: Conventional mechanical ventilation; ECMO: Extracorporeal Membrane Oxygenation; ELSO: Extracorporeal Life Support Organization; HFOV: High-frequency oscillatory ventilation; iNO: Inhaled nitric oxide; LHR: Lung to head ratio; PPHN: Persistent pulmonary hypertension of newborn

\section{Acknowledgements \\ Not applicable}

\section{Funding}

Praveen Chandrasekharan - Salary support from University at Buffalo - Dr. Henry C. and Bertha H. Buswell Fellowship.

Satyan Lakshminrusimha - grant 1R01HD072929-0 (SL) and Women and Children's Hospital of Buffalo Foundation.

\section{Availability of data and materials} Not applicable

\section{Authors' contributions}

PKC: concept, collection of data, writing the manuscript, critique and revision. MR: concept, collection of data, writing the manuscript, critique and revision. RM: Contributed to management, critique and revision. DR: Wrote the surgical management section, contributed to ECMO management, revised and critiqued. Surgical correction with Goretex patch copyrighted to DR. SL: mentor, concept, collection of data, writing the manuscript, critique and responsible for all illustration/figures. Illustrations copyrighted to SL. All authors read and approved the final manuscript.

\section{Authors information}

Praveen Kumar Chandrasekharan, Attending - Neonatology, Research Assistant Professor.

Department of Pediatrics, Women and Children's Hospital of Buffalo, Buffalo, NY. Munmun Rawat, Attending - Neonatology, Research Assistant Professor. Department of Pediatrics, Women and Children's Hospital of Buffalo, Buffalo, NY. Rajeshwari Madappa, Pediatrician.

SIGMA Hospital, Mysore, India.

David H. Rothstein, Pediatric Surgeon, Associate Professor. 
Department of Pediatric Surgery, Women and Children's Hospital of Buffalo, Buffalo, NY.

Satyan Lakshminrusimha, Chief of Neonatology, Vice Chair and Professor of Pediatrics.

Department of Pediatrics, Women and Children's Hospital of Buffalo, Buffalo, NY.

\section{Competing interests}

The authors declare that they have no competing interests.

\section{Consent for publication}

All authors consent for publication.

\section{Ethics approval and consent to participate}

Not applicable.

\section{Author details}

'Department of Pediatrics, Women and Children's Hospital of Buffalo, Buffalo, NY, USA. ${ }^{2}$ SIGMA Hospital, Mysore, India. 'Department of Pediatric Surgery, Women and Children's Hospital of Buffalo, Buffalo, NY, USA.

\section{Received: 13 November 2016 Accepted: 28 February 2017} Published online: 11 March 2017

\section{References}

1. Colvin J, Bower C, Dickinson JE, Sokol J. Outcomes of congenital diaphragmatic hernia: a population-based study in Western Australia. Pediatrics. 2005;116(3):e356-363.

2. Gallot D, Boda C, Ughetto S, Perthus I, Robert-Gnansia E, Francannet C, Laurichesse-Delmas H, Jani J, Coste K, Deprest J, et al. Prenatal detection and outcome of congenital diaphragmatic hernia: a French registry-based study. Ultrasound Obstet Gynecol. 2007;29(3):276-83.

3. Yang W, Carmichael SL, Harris JA, Shaw GM. Epidemiologic characteristics of congenital diaphragmatic hernia among 2.5 million California births, 19891997. Birth Defects Res A Clin Mol Teratol. 2006;76(3):170-4.

4. McGivern MR, Best KE, Rankin J, Wellesley D, Greenlees R, Addor MC, Arriola $L$, de Walle H, Barisic I, Beres J, et al. Epidemiology of congenital diaphragmatic hernia in Europe: a register-based study. Arch Dis Child Fetal Neonatal Ed. 2015;100(2):F137-144.

5. Tennant PW, Samarasekera SD, Pless-Mulloli T, Rankin J. Sex differences in the prevalence of congenital anomalies: a population-based study. Birth Defects Res A Clin Mol Teratol. 2011;91(10):894-901.

6. Brownlee EM, Howatson AG, Davis CF, Sabharwal AJ. The hidden mortality of congenital diaphragmatic hernia: a 20-year review. J Pediatr Surg. 2009; 44(2):317-20.

7. Mah VK, Zamakhshary M, Mah DY, Cameron B, Bass J, Bohn D, Scott L, Himidan S, Walker M, Kim PC. Absolute vs relative improvements in congenital diaphragmatic hernia survival: what happened to "hidden mortality". J Pediatr Surg. 2009;44(5):877-82.

8. Stege G, Fenton A, Jaffray B. Nihilism in the 1990s: the true mortality of congenital diaphragmatic hernia. Pediatrics. 2003;112(3 Pt 1):532-5.

9. Beurskens LW, Tibboel D, Lindemans J, Duvekot JJ, Cohen-Overbeek TE, Veenma DC, de Klein A, Greer JJ, Steegers-Theunissen RP. Retinol status of newborn infants is associated with congenital diaphragmatic hernia. Pediatrics. 2010;126(4):712-20.

10. Beurskens LW, Tibboel D, Steegers-Theunissen RP. Role of nutrition, lifestyle factors, and genes in the pathogenesis of congenital diaphragmatic hernia: human and animal studies. Nutr Rev. 2009;67(12):719-30.

11. Wat MJ, Veenma D, Hogue J, Holder AM, Yu Z, Wat JJ, Hanchard N, Shchelochkov OA, Fernandes CJ, Johnson A, et al. Genomic alterations that contribute to the development of isolated and non-isolated congenital diaphragmatic hernia. J Med Genet. 2011;48(5):299-307.

12. Anderson D. Incidence of congenital diaphragmatic hernia in the young of rats bred on a diet deficient in Vitamin A. Am J Dis Child. 1941;62:888-9.

13. Tenbrinck R, Tibboel D, Gaillard JL, Kluth D, Bos AP, Lachmann B, Molenaar $J C$. Experimentally induced congenital diaphragmatic hernia in rats. J Pediatr Surg. 1990;25(4):426-9.

14. Tenbrinck R, Gaillard JL, Tibboel D, Kluth D, Lachmann B, Molenaar JC. Pulmonary vascular abnormalities in experimentally induced congenital diaphragmatic hernia in rats. J Pediatr Surg. 1992;27(7):862-5.
15. Major D, Cadenas M, Fournier L, Leclerc S, Lefebvre M, Cloutier R. Retinol status of newborn infants with congenital diaphragmatic hernia. Pediatr Surg Int. 1998;13(8):547-9.

16. Greer JJ. Current concepts on the pathogenesis and etiology of congenital diaphragmatic hernia. Respir Physiol Neurobiol. 2013;189(2):232-40.

17. Veenma DC, de Klein A, Tibboel D. Developmental and genetic aspects of congenital diaphragmatic hernia. Pediatr Pulmonol. 2012;47(6):534-45.

18. Moore KL, Persaud TV, Torchia MG. The developing human: clinically oriented embryology. 2011.

19. Wells LJ. Development of the human diaphragm and pleural sacs. Contrib Embryol Carnegie Ins. 1954;35:107-34

20. Harrison MR. The fetus with a diaphragmatic hernia: pathophysiology, natural history, and surgical management. In: The unborn patient fetal diagnosis and treatment. 2nd ed. Philadelphia: W.B. Saunders; 1990. p. 259-319.

21. Iritani I. Experimental study on embryogenesis of congenital diaphragmatic hernia. Anat Embryol (Berl). 1984;169(2):133-9.

22. Mayer $S$, Metzger R, Kluth $D$. The embryology of the diaphragm. Semin Pediatr Surg. 2011;20(3):161-9.

23. Aggarwal S, Stockman PT, Klein MD, Natarajan G. The right ventricular systolic to diastolic duration ratio: a simple prognostic marker in congenital diaphragmatic hernia? Acta Paediatr. 2011;100(10):1315-8.

24. Irish MS, Karamanoukian HL, OToole SJ, Glick PL. You gotta have heart. J Pediatr. 1996;129(1):175-6. author reply 176-177.

25. Menon SC, Tani LY, Weng HY, Lally PA, Lally KP, Yoder BA, Congenital Diaphragmatic Hernia Study G. Clinical characteristics and outcomes of patients with cardiac defects and congenital diaphragmatic hernia. J Pediatr. 2012;162:114-9.

26. Schwartz SM, Vermilion RP, Hirschl RB. Evaluation of left ventricular mass in children with left-sided congenital diaphragmatic hernia. J Pediatr. 1994; 125(3):447-51.

27. Keijzer R, Liu J, Deimling J, Tibboel D, Post M. Dual-hit hypothesis explains pulmonary hypoplasia in the nitrofen model of congenital diaphragmatic hernia. Am J Pathol. 2000;156(4):1299-306.

28. George DK, Cooney TP, Chiu BK, Thurlbeck WM. Hypoplasia and immaturity of the terminal lung unit (acinus) in congenital diaphragmatic hernia. Am Rev Respir Dis. 1987;136(4):947-50.

29. DiFiore JW, Fauza DO, Slavin R, Wilson JM. Experimental fetal tracheal ligation and congenital diaphragmatic hernia: a pulmonary vascular morphometric analysis. J Pediatr Surg. 1995;30(7):917-23. discussion 923-914.

30. Lakshminrusimha $\mathrm{S}$. The pulmonary circulation in neonatal respiratory failure. Clin Perinatol. 2012;39(3):655-83.

31. Kitagawa M, Hislop A, Boyden EA, Reid L. Lung hypoplasia in congenital diaphragmatic hernia. A quantitative study of airway, artery, and alveolar development. Br J Surg. 1971;58(5):342-6.

32. Shehata SM, Mooi WJ, Okazaki T, El-Banna I, Sharma HS, Tibboel D. Enhanced expression of vascular endothelial growth factor in lungs of newborn infants with congenital diaphragmatic hernia and pulmonary hypertension. Thorax. 1999;54(5):427-31.

33. Pierro M, Thebaud B. Understanding and treating pulmonary hypertension in congenital diaphragmatic hernia. Semin Fetal Neonatal Med. 2014;19(6): 357-63.

34. Sluiter I, van der Horst I, van der Voorn P, Boerema-de Munck A, Buscop-van Kempen M, de Krijger R, Tibboel D, Reiss I, Rottier RJ. Premature differentiation of vascular smooth muscle cells in human congenital diaphragmatic hernia. Exp Mol Pathol. 2013;94(1):195-202.

35. Lath NR, Galambos C, Rocha AB, Malek M, Gittes GK, Potoka DA. Defective pulmonary innervation and autonomic imbalance in congenital diaphragmatic hernia. Am J Physiol Lung Cell Mol Physiol. 2012;302(4):L390-398.

36. Luong C, Rey-Perra J, Vadivel A, Gilmour G, Sauve Y, Koonen D, Walker D, Todd KG, Gressens P, Kassiri Z, et al. Antenatal sildenafil treatment attenuates pulmonary hypertension in experimental congenital diaphragmatic hernia. Circulation. 2011;123(19):2120-31.

37. Schmidt AF, Rojas-Moscoso JA, Goncalves FL, Gallindo RM, Monica FZ, Antunes E, Figueira RL, Sbragia L. Increased contractility and impaired relaxation of the left pulmonary artery in a rabbit model of congenital diaphragmatic hernia. Pediatr Surg Int. 2013;29(5):489-94.

38. Shinkai T, Shima H, Solari V, Puri P. Expression of vasoactive mediators during mechanical ventilation in nitrofen-induced diaphragmatic hernia in rats. Pediatr Surg Int. 2005;21(3):143-7.

39. Nair J, Lakshminrusimha S. Update on PPHN: mechanisms and treatment. Semin Perinatol. 2014;38(2):78-91. 
40. Siebert JR, Haas JE, Beckwith JB. Left ventricular hypoplasia in congenital diaphragmatic hernia. J Pediatr Surg. 1984;19(5):567-71.

41. Byrne FA, Keller RL, Meadows J, Miniati D, Brook MM, Silverman NH, MoonGrady AJ. Severe left diaphragmatic hernia limits size of fetal left heart more than right diaphragmatic hernia. Ultrasound Obstet Gynecol. 2015;46:688-94.

42. Kinsella JP, Ivy DD, Abman SH. Pulmonary vasodilator therapy in congenital diaphragmatic hernia: acute, late, and chronic pulmonary hypertension. Semin Perinatol. 2005;29(2):123-8.

43. Graham G, Devine PC. Antenatal diagnosis of congenital diaphragmatic hernia. Semin Perinatol. 2005;29(2):69-76.

44. Garne E, Haeusler M, Barisic I, Gjergja R, Stoll C, Clementi M, Euroscan Study G. Congenital diaphragmatic hernia: evaluation of prenatal diagnosis in 20 european regions. Ultrasound Obstet Gynecol. 2002;19(4):329-33.

45. Quinn TM, Hubbard AM, Adzick NS. Prenatal magnetic resonance imaging enhances fetal diagnosis. J Pediatr Surg. 1998;33(4):553-8.

46. Worley KC, Dashe JS, Barber RG, Megison SM, McIntire DD, Twickler DM. Fetal magnetic resonance imaging in isolated diaphragmatic hernia: volume of herniated liver and neonatal outcome. Am J Obstet Gynecol. 2009;200(3): 318 e311-316.

47. Sweed Y, Puri P. Congenital diaphragmatic hernia: influence of associated malformations on survival. Arch Dis Child. 1993;69(1 Spec No):68-70.

48. Pober BR, Lin A, Russell M, Ackerman KG, Chakravorty S, Strauss B, Westgate MN, Wilson J, Donahoe PK, Holmes LB. Infants with bochdalek diaphragmatic hernia: sibling precurrence and monozygotic twin discordance in a hospital-based malformation surveillance program. Am J Med Genet A. 2005;138A(2):81-8.

49. Slavotinek AM. Fryns syndrome: a review of the phenotype and diagnostic guidelines. Am J Med Genet A. 2004;124A(4):427-33.

50. Deprest J, Brady P, Nicolaides K, Benachi A, Berg C, Vermeesch J, Gardener $G$, Gratacos E. Prenatal management of the fetus with isolated congenital diaphragmatic hernia in the era of the TOTAL trial. Semin Fetal Neonatal Med. 2014;19(6):338-48.

51. Tennant PW, Pearce MS, Bythell M, Rankin J. 20-year survival of children born with congenital anomalies: a population-based study. Lancet. 2010; 375(9715):649-56.

52. Metkus AP, Filly RA, Stringer MD, Harrison MR, Adzick NS. Sonographic predictors of survival in fetal diaphragmatic hernia. J Pediatr Surg. 1996; 31(1):148-51. discussion 151-142.

53. Singh SJ, Cummins GE, Cohen RC, Cass D, Harvey JG, Martin HC, Pitkin J, Shun A, Glasson MJ. Adverse outcome of congenital diaphragmatic hernia is determined by diaphragmatic agenesis, not by antenatal diagnosis. J Pediatr Surg. 1999;34(11):1740-2.

54. Mullassery D, Ba'ath ME, Jesudason EC, Losty PD. Value of liver herniation in prediction of outcome in fetal congenital diaphragmatic hernia: a systematic review and meta-analysis. Ultrasound Obstet Gynecol. 2010;35(5):609-14.

55. Hedrick HL, Danzer E, Merchant A, Bebbington MW, Zhao H, Flake AW Johnson MP, Liechty KW, Howell LJ, Wilson RD, et al. Liver position and lung-to-head ratio for prediction of extracorporeal membrane oxygenation and survival in isolated left congenital diaphragmatic hernia. Am J Obstet Gynecol. 2007;197(4):422 e421-424.

56. Lipshutz GS, Albanese CT, Feldstein VA, Jennings RW, Housley HT, Beech R, Farrell JA, Harrison MR. Prospective analysis of lung-to-head ratio predicts survival for patients with prenatally diagnosed congenital diaphragmatic hernia. J Pediatr Surg. 1997;32(11):1634-6.

57. Peralta CF, Cavoretto P, Csapo B, Vandecruys H, Nicolaides KH. Assessment of lung area in normal fetuses at 12-32 weeks. Ultrasound Obstet Gynecol. 2005;26(7):718-24.

58. Ba'ath ME, Jesudason EC, Losty PD. How useful is the lung-to-head ratio in predicting outcome in the fetus with congenital diaphragmatic hernia? a systematic review and meta-analysis. Ultrasound Obstet Gynecol. 2007;30(6): 897-906.

59. Jani J, Nicolaides KH, Keller RL, Benachi A, Peralta CF, Favre R, Moreno O, Tibboel D, Lipitz S, Eggink A, et al. Observed to expected lung area to head circumference ratio in the prediction of survival in fetuses with isolated diaphragmatic hernia. Ultrasound Obstet Gynecol. 2007;30(1):67-71.

60. Kapur P, Holm BA, Irish MS, Sokolowski J, Patel A, Glick PL. Lung physiological and metabolic changes in lambs with congenital diaphragmatic hernia after administration of prenatal maternal corticosteroids. J Pediatr Surg. 1999;34(2):354-6.

61. Lally KP, Bagolan P, Hosie S, Lally PA, Stewart M, Cotten CM, Van Meurs KP, Alexander G, Congenital Diaphragmatic Hernia Study G. Corticosteroids for fetuses with congenital diaphragmatic hernia: can we show benefit? J Pediatr Surg. 2006:41(4):668-74. discussion 668-674.

62. Junior EA, Tonni G, Martins WP, Ruano R. Procedure-Related Complications and Survival Following Fetoscopic Endotracheal Occlusion (FETO) for Severe Congenital Diaphragmatic Hernia: Systematic Review and Meta-Analysis in the FETO Era. Eur J Pediatr Surg. 2016. doi:10.1055/s-0036-1587331.

63. Stevens TP, van Wijngaarden E, Ackerman KG, Lally PA, Lally KP. Timing of delivery and survival rates for infants with prenatal diagnoses of congenital diaphragmatic hernia. Pediatrics. 2009;123(2):494-502.

64. Hutcheon JA, Butler B, Lisonkova S, Marquette GP, Mayer C, Skoll A, Joseph KS. Timing of delivery for pregnancies with congenital diaphragmatic hernia. BJOG. 2010;117(13):1658-62.

65. Sengupta S, Carrion V, Shelton J, Wynn RJ, Ryan RM, Singhal K, Lakshminrusimha S. Adverse neonatal outcomes associated with early-term birth. JAMA Pediatr. 2013;167(11):1053-9.

66. Kattwinkel J, Perlman JM, Aziz K, Colby C, Fairchild K, Gallagher J, Hazinski MF, Halamek LP, Kumar P, Little G, et al. Part 15: neonatal resuscitation: 2010 american heart association guidelines for cardiopulmonary resuscitation and emergency cardiovascular care. Circulation. 2010;122(18 Suppl 3):S909-919.

67. Gien J, Kinsella JP. Differences in preductal and postductal arterial blood gas measurements in infants with severe congenital diaphragmatic hernia. Arch Dis Child Fetal Neonatal Ed. 2016;101(4):F314-318.

68. Snoek KG, Capolupo I, van Rosmalen J, Hout Lde J, Vijfhuize S, Greenough A, Wijnen RM, Tibboel D, Reiss IK, Consortium CE. Conventional mechanical ventilation versus high-frequency oscillatory ventilation for congenital Diaphragmatic hernia: a randomized clinical trial (the VICl-trial). Ann Surg. 2016;263(5):867-74.

69. Sakurai Y, Azarow K, Cutz E, Messineo A, Pearl R, Bohn D. Pulmonary barotrauma in congenital Diaphragmatic hernia: a clinicopathological correlation. J Pediatr Surg. 1999;34(12):1813-7.

70. Wung JT, Sahni R, Moffitt ST, Lipsitz E, Stolar CJ. Congenital diaphragmatic hernia: survival treated with very delayed surgery, spontaneous respiration, and no chest tube. J Pediatr Surg. 1995;30(3):406-9.

71. Reiss I, Schaible T, van den Hout L, Capolupo I, Allegaert K, van Heijst A, Gorett Silva M, Greenough A, Tibboel D, Consortium CE. Standardized postnatal management of infants with congenital diaphragmatic hernia in Europe: the CDH EURO consortium consensus. Neonatology. 2010;98(4): 354-64.

72. Habib RH, Pyon KH, Courtney SE. Optimal high-frequency oscillatory ventilation settings by nonlinear lung mechanics analysis. Am J Respir Crit Care Med. 2002;166(7):950-3.

73. van den Hout L, Tibboel D, Vijfhuize S, te Beest H, Hop W, Reiss I, Consortium C-E. The VICl-trial: high frequency oscillation versus conventional mechanical ventilation in newborns with congenital diaphragmatic hernia: an international multicentre randomized controlled trial. BMC Pediatr. 2011;11:98

74. Van Meurs K, Congenital Diaphragmatic Hernia Study G. Is surfactant therapy beneficial in the treatment of the term newborn infant with congenital diaphragmatic hernia? J Pediatr. 2004;145(3):312-6.

75. Lally KP, Lally PA, Langham MR, Hirschl R, Moya FR, Tibboel D, Van Meurs K, Congenital Diaphragmatic Hernia Study G. Surfactant does not improve survival rate in preterm infants with congenital diaphragmatic hernia. J Pediatr Surg. 2004;39(6):829-33.

76. Hagadorn JI, Brownell EA, Herbst KW, Trzaski JM, Neffs S, Campbell BT. Trends in treatment and in-hospital mortality for neonates with congenital diaphragmatic hernia. J Perinatol. 2015;35:748-54.

77. Noori S, Seri I. Neonatal blood pressure support: the use of inotropes, lusitropes, and other vasopressor agents. Clin Perinatol. 2012;39(1):221-38.

78. Seri I, Tan R, Evans J. Cardiovascular effects of hydrocortisone in preterm infants with pressor-resistant hypotension. Pediatrics. 2001;107(5):1070-4.

79. Acker SN, Kinsella JP, Abman SH, Gien J. Vasopressin improves hemodynamic status in infants with congenital diaphragmatic hernia. J Pediatr. 2014;165(1):53-8. e51.

80. Sharma V, Berkelhamer S, Lakshminrusimha S. Persistent pulmonary hypertension of the newborn. Maternal Health, Neonatology Perinatol. 2015;1(1):14.

81. Suda K, Bigras JL, Bohn D, Hornberger LK, McCrindle BW. Echocardiographic predictors of outcome in newborns with congenital diaphragmatic hernia. Pediatrics. 2000;105(5):1106-9.

82. Tourneux P, Rakza T, Bouissou A, Krim G, Storme L. Pulmonary circulatory effects of norepinephrine in newborn infants with persistent pulmonary hypertension. J Pediatr. 2008;153(3):345-9. 
83. Snoek KG, Reiss IK, Greenough A, Capolupo I, Urlesberger B, Wessel L, Storme L, Deprest J, Schaible T, van Heijst A, et al. Standardized postnatal management of infants with congenital diaphragmatic hernia in Europe: the CDH EURO consortium consensus - 2015 update. Neonatology. 2016; 110(1):66-74.

84. Rawat M, Chandrasekharan PK, Williams A, Gugino S, Koenigsknecht C, Swartz D, Ma CX, Mathew B, Nair J, Lakshminrusimha S. Oxygen saturation index and severity of hypoxic respiratory failure. Neonatology. 2015;107(3): 161-6.

85. Thomas NJ, Shaffer ML, Willson DF, Shih MC, Curley MA. Defining acute lung disease in children with the oxygenation saturation index. Pediatr Crit Care Med. 2010;11(1):12-7.

86. Davidson D, Barefield ES, Kattwinkel J, Dudell G, Damask M, Straube R, Rhines J, Chang CT. Inhaled nitric oxide for the early treatment of persistent pulmonary hypertension of the term newborn: a randomized, doublemasked, placebo-controlled, dose-response, multicenter study. The I-NO/ PPHN study group. Pediatrics. 1998;101(3 Pt 1):325-34.

87. Konduri GG, Kim UO. Advances in the diagnosis and management of persistent pulmonary hypertension of the newborn. Pediatr Clin North Am. 2009;56(3):579-600. Table of Contents.

88. Kinsella JP. Inhaled nitric oxide in the term newborn. Early Hum Dev. 2008 84(11):709-16.

89. Konduri GG, Solimano A, Sokol GM, Singer J, Ehrenkranz RA, Singhal N, Wright LL, Van Meurs K, Stork E, Kirpalani H, et al. A randomized trial of early versus standard inhaled nitric oxide therapy in term and near-term newborn infants with hypoxic respiratory failure. Pediatrics. 2004;113(3 Pt 1):559-64.

90. Neonatal Inhaled Nitric Oxide Study Group. Inhaled nitric oxide and hypoxic respiratory failure in infants with congenital diaphragmatic hernia. The neonatal inhaled nitric oxide study group (NINOS). Pediatrics. 1997;99(6): 838-45

91. Campbell BT, Herbst KW, Briden KE, Neff S, Ruscher KA, Hagadorn JI. Inhaled nitric oxide use in neonates with congenital diaphragmatic hernia. Pediatrics. 2014;134(2):e420-426.

92. Iocono JA, Cilley RE, Mauger DT, Krummel TM, Dillon PW. Postnatal pulmonary hypertension after repair of congenital diaphragmatic hernia: predicting risk and outcome. J Pediatr Surg. 1999;34(2):349-53.

93. Schwartz IP, Bernbaum JC, Rychik J, Grunstein M, D'Agostino J, Polin RA. Pulmonary hypertension in children following extracorporeal membrane oxygenation therapy and repair of congenital diaphragmatic hernia. J Perinatol. 1999;19(3):220-6.

94. Mohseni-Bod H, Bohn D. Pulmonary hypertension in congenital diaphragmatic hernia. Semin Pediatr Surg. 2007;16(2):126-33.

95. Inamura N, Kubota A, Nakajima T, Kayatani F, Okuyama H, Oue T, Kawahara H. A proposal of new therapeutic strategy for antenatally diagnosed congenital diaphragmatic hernia. J Pediatr Surg. 2005;40(8):1315-9.

96. Shiyanagi S, Okazaki T, Shoji H, Shimizu T, Tanaka T, Takeda S, Kawashima K, Lane GJ, Yamataka A. Management of pulmonary hypertension in congenital diaphragmatic hernia: nitric oxide with prostaglandin-E1 versus nitric oxide alone. Pediatr Surg Int. 2008;24(10):1101-4.

97. Baquero H, Soliz A, Neira F, Venegas ME, Sola A. Oral sildenafil in infants with persistent pulmonary hypertension of the newborn: a pilot randomized blinded study. Pediatrics. 2006;117(4):1077-83.

98. Vargas-Origel A, Gomez-Rodriguez G, Aldana-Valenzuela C, Vela-Huerta MM, Alarcon-Santos SB, Amador-Licona N. The use of sildenafil in persistent pulmonary hypertension of the newborn. Am J Perinatol. 2010;27(3):225-30.

99. Steinhorn RH, Kinsella JP, Pierce C, Butrous G, Dilleen M, Oakes M, Wessel DL. Intravenous sildenafil in the treatment of neonates with persistent pulmonary hypertension. J Pediatr. 2009;155(6):841-7. e841.

100. Abman SH, Kinsella JP, Rosenzweig EB, Krishnan U, Kulik T, Mullen M, Wessel DL, Steinhorn R, Adatia I, Hanna B, et al. Implications of the U.S. Food and drug administration warning against the use of sildenafil for the treatment of pediatric pulmonary hypertension. Am J Respir Crit Care Med. 2013; 187(6):572-5.

101. Lakshminrusimha S, Porta NF, Farrow KN, Chen B, Gugino SF, Kumar VH, Russell JA, Steinhorn RH. Milrinone enhances relaxation to prostacyclin and Iloprost in pulmonary arteries isolated from lambs with persistent pulmonary hypertension of the newborn. Pediatr Crit Care Med. 2009; 10(1):106-12.

102. Hoffman TM, Wernovsky G, Atz AM, Bailey JM, Akbary A, Kocsis JF, Nelson DP, Chang AC, Kulik TJ, Spray TL, et al. Prophylactic intravenous use of milrinone after cardiac operation in pediatrics (PRIMACORP) study.
Prophylactic intravenous use of milrinone after cardiac operation in pediatrics. Am Heart J. 2002;143(1):15-21.

103. Patel N. Use of milrinone to treat cardiac dysfunction in infants with pulmonary hypertension secondary to congenital diaphragmatic hernia: a review of six patients. Neonatology. 2012;102(2):130-6.

104. Bassler D, Choong K, McNamara P, Kirpalani H. Neonatal persistent pulmonary hypertension treated with milrinone: four case reports. Biol Neonate. 2006;89(1):1-5.

105. McNamara PJ, Laique F, Muang-In S, Whyte HE. Milrinone improves oxygenation in neonates with severe persistent pulmonary hypertension of the newborn. J Crit Care. 2006;21(2):217-22

106. McNamara PJ, Shivananda SP, Sahni M, Freeman D, Taddio A. Pharmacology of milrinone in neonates with persistent pulmonary hypertension of the newborn and suboptimal response to inhaled nitric oxide. Pediatr Crit Care Med. 2013;14(1):74-84.

107. Bailey JM, Hoffman TM, Wessel DL, Nelson DP, Atz AM, Chang AC, Kulik TJ, Spray TL, Akbary A, Miller RP, et al. A population pharmacokinetic analysis of milrinone in pediatric patients after cardiac surgery. J Pharmacokinet Pharmacodyn. 2004;31(1):43-59.

108. Lakshminrusimha S, Keszler M. Persistent Pulmonary Hypertension of the Newborn. Neoreviews. 2015;16(12):e680-92.

109. Steinhorn RH, Fineman J, Kusic-Pajic A, Cornelisse P, Gehin M, Nowbakht P, Pierce CM, Beghetti M, investigators F-s. Bosentan as adjunctive therapy for persistent pulmonary hypertension of the newborn: results of the randomized multicenter placebo-controlled exploratory trial. J Pediatr. 2016; 177:90-6. e93.

110. Dimmitt RA, Moss RL, Rhine WD, Benitz WE, Henry MC, Vanmeurs KP. Venoarterial versus venovenous extracorporeal membrane oxygenation in congenital diaphragmatic hernia: the extracorporeal life support organization registry, 1990-1999. J Pediatr Surg. 2001;36(8):1199-204.

111. Guner YS, Khemani RG, Qureshi FG, Wee CP, Austin MT, Dorey F, Rycus PT, Ford HR, Friedlich P, Stein JE. Outcome analysis of neonates with congenital diaphragmatic hernia treated with venovenous vs venoarterial extracorporeal membrane oxygenation. J Pediatr Surg. 2009;44(9):1691-701.

112. Haricharan RN, Barnhart DC, Cheng H, Delzell E. Identifying neonates at a very high risk for mortality among children with congenital diaphragmatic hernia managed with extracorporeal membrane oxygenation. J Pediatr Surg. 2009;44(1):87-93.

113. Kays DW, Islam S, Richards DS, Larson SD, Perkins JM, Talbert JL. Extracorporeal life support in patients with congenital diaphragmatic hernia: how long should we treat? J Am Coll Surg. 2014;218(4):808-17.

114. Seetharamaiah R, Younger JG, Bartlett RH, Hirschl RB, Congenital Diaphragmatic Hernia Study G. Factors associated with survival in infants with congenital diaphragmatic hernia requiring extracorporeal membrane oxygenation: a report from the congenital diaphragmatic hernia study group. J Pediatr Surg. 2009;44(7):1315-21.

115. Tsao K, Lally KP. Surgical management of the newborn with congenital diaphragmatic hernia. Fetal Diagn Ther. 2011;29(1):46-54.

116. Desai AA, Ostlie DJ, Juang D. Optimal timing of congenital diaphragmatic hernia repair in infants on extracorporeal membrane oxygenation. Semin Pediatr Surg. 2015;24(1):17-9.

117. Gander JW, Fisher JC, Gross ER, Reichstein AR, Cowles RA, Aspelund G, Stolar $\mathrm{CJ}$, Kuenzler KA. Early recurrence of congenital diaphragmatic hernia is higher after thoracoscopic than open repair: a single institutional study. J Pediatr Surg. 2011;46(7):1303-8.

118. Grethel EJ, Cortes RA, Wagner AJ, Clifton MS, Lee H, Farmer DL, Harrison MR, Keller RL, Nobuhara KK. Prosthetic patches for congenital diaphragmatic hernia repair: surgisis vs gore-Tex. J Pediatr Surg. 2006;41(1):29-33. discussion 29-33.

119. Brant-Zawadzki PB, Fenton SJ, Nichol PF, Matlak ME, Scaife ER. The split abdominal wall muscle flap repair for large congenital diaphragmatic hernias on extracorporeal membrane oxygenation. J Pediatr Surg. 2007; 42(6):1047-50. discussion 1051

120. Lally KP, Engle W, American Academy of Pediatrics Section on S, American Academy of Pediatrics Committee on F, Newborn. Postdischarge follow-up of infants with congenital diaphragmatic hernia. Pediatrics. 2008;121(3):627-32.

121. Muratore CS, Kharasch V, Lund DP, Sheils C, Friedman S, Brown C, Utter S, Jaksic T, Wilson JM. Pulmonary morbidity in 100 survivors of congenital diaphragmatic hernia monitored in a multidisciplinary clinic. J Pediatr Surg. 2001;36(1):133-40. 
122. Trachsel D, Selvadurai H, Bohn D, Langer JC, Coates AL. Long-term pulmonary morbidity in survivors of congenital diaphragmatic hernia. Pediatr Pulmonol. 2005;39(5):433-9.

123. Peetsold MG, Kneepkens CM, Heij HA, IJsselstijn H, Tibboel D, Gemke RJ. Congenital diaphragmatic hernia: long-term risk of gastroesophageal reflux disease. J Pediatr Gastroenterol Nutr. 2010;51(4):448-53.

124. Morandi A, Macchini F, Zanini A, Pasqua N, Farris G, Canazza L, Gentilino V Di Cesare A, Leva E. Endoscopic surveillance for congenital diaphragmatic hernia: unexpected prevalence of silent esophagitis. Eur J Pediatr Surg. 2015;26:291-5.

125. Morini F, Capolupo I, Masi R, Ronchetti MP, Locatelli M, Corchia C, Bagolan P. Hearing impairment in congenital diaphragmatic hernia: the inaudible and noiseless foot of time. J Pediatr Surg. 2008;43(2):380-4.

126. Partridge EA, Bridge C, Donaher JG, Herkert LM, Grill E, Danzer E, Gerdes M, Hoffman CH, D'Agostino JA, Bernbaum JC, et al. Incidence and factors associated with sensorineural and conductive hearing loss among survivors of congenital diaphragmatic hernia. J Pediatr Surg. 2014;49(6):890-4. discussion 894.

127. Russell KW, Barnhart DC, Rollins MD, Hedlund G, Scaife ER. Musculoskeletal deformities following repair of large congenital diaphragmatic hernias. J Pediatr Surg. 2014;49(6):886-9.

128. Tsao K, Lally KP. The congenital diaphragmatic hernia study group: a voluntary international registry. Semin Pediatr Surg. 2008;17(2):90-7.

129. Wynn J, Krishnan U, Aspelund G, Zhang Y, Duong J, Stolar CJ, Hahn E, Pietsch J, Chung D, Moore D, et al. Outcomes of congenital diaphragmatic hernia in the modern era of management. J Pediatr. 2013;163(1):114-9. e111.

\section{Submit your next manuscript to BioMed Central} and we will help you at every step:

- We accept pre-submission inquiries

- Our selector tool helps you to find the most relevant journal

- We provide round the clock customer support

- Convenient online submission

- Thorough peer review

- Inclusion in PubMed and all major indexing services

- Maximum visibility for your research

Submit your manuscript at www.biomedcentral.com/submit

C) Biomed Central 